\title{
Metallophosphites as Umpolung Catalysts: The Enantioselective Cross Silyl Benzoin Reaction
}

\author{
Xin Linghu, Justin P. Potnick and Jeffrey S. Johnson* \\ Department of Chemistry, University of North Carolina at Chapel Hill, \\ Chapel Hill, North Carolina 27599-3290
}

\section{Supporting Information}

\section{Experimental Section}

Materials and Methods: General. Infrared (IR) spectra were obtained using a Nicolet 560-E.S.P. infrared spectrometer. Optical rotations were measured using a JASCO P-1010 polarimeter. Proton and carbon nuclear magnetic resonance spectra $\left({ }^{1} \mathrm{H},{ }^{13} \mathrm{C}\right.$ and $\left.{ }^{31} \mathrm{P} \mathrm{NMR}\right)$ were recorded on the following instruments: Bruker model Avance $400\left({ }^{1} \mathrm{H} \mathrm{NMR}\right.$ at $400 \mathrm{MHz},{ }^{13} \mathrm{C}$ NMR at $100 \mathrm{MHz}$, and ${ }^{31} \mathrm{P}$ NMR at $\left.162 \mathrm{MHz}\right)$ and Varian Gemini $300\left({ }^{1} \mathrm{H}\right.$ NMR at $300 \mathrm{MHz}$ and ${ }^{13} \mathrm{C}$ at $\left.75 \mathrm{MHz}\right)$ spectrometers with solvent resonance as the internal standard $\left({ }^{1} \mathrm{H} \mathrm{NMR}: \mathrm{CDCl}_{3}\right.$ at 7.26 ppm, and ${ }^{13} \mathrm{C}$ NMR: $\mathrm{CDCl}_{3}$ at $\left.77.0 \mathrm{ppm}\right)$ or with phosphoric acid as external standard $\left({ }^{31} \mathrm{P}\right.$ NMR: phosphoric acid at $0 \mathrm{ppm}) .{ }^{1} \mathrm{H}$ NMR data are reported as follows: chemical shift, multiplicity $(\mathrm{s}=$ singlet, $\mathrm{d}=$ doublet, $\mathrm{t}=$ triplet, $\mathrm{q}=$ quartet, $\mathrm{sep}=$ septet, $\mathrm{m}=$ multiplet $)$, coupling constants $(\mathrm{Hz})$, and integration. Enantiomeric excesses (ee) were obtained using a Berger Supercritical Fluid Chromatograph (SFC) model FCM 1100/1200 equipped with an Agilent 1100 series UV-Vis detector using one of the four following chiral HPLC columns: Chiralpak AD (250 x $4.6 \mathrm{~mm})$, Chiralpak AS $(250 \times 4.6 \mathrm{~mm})$ columns, Chiralcel OD-H $(250 \times 4.6 \mathrm{~mm})$ or Regis Pirkle $(S, S)$-Whelk-O1 $(250 \times 4.6 \mathrm{~mm})$. Samples were eluted with $\mathrm{SFC}$ grade $\mathrm{CO}_{2}$ and the indicated percentage of $\mathrm{MeOH}$. Analytical thin layer chromatography (TLC) was performed on Silicycle $0.25 \mathrm{~mm}$ silica gel 60 plates. Visualization was accomplished with UV light and aqueous ceric ammonium nitrate molybdate solution followed by heating. Purification of the reaction products was carried out by flash chromatography using Silicycle silica gel 60 (32-63 $\mu \mathrm{m})$. All reactions were carried out under an atmosphere of argon in flame-dried glassware with magnetic stirring. Diethyl ether and toluene were dried by passage through a column of neutral alumina under nitrogen prior to use. ${ }^{1}$ Tetrahydrofuran was distilled over sodium and benzophenone under nitrogen prior to use. Unless otherwise noted, reagents were obtained from commercial sources and used without further purification. Yield refers to isolated yield of analytically pure material. Yields and enantiomeric excesses are reported for a specific experiment and as a result may differ slightly from those found in the tables, which are averages of at least two experiments. Acylsilanes were prepared through 3 steps from the corresponding aldehydes. ${ }^{2}$ $(R, R)$-TADDOLs were prepared in 2 steps from the commercially available $L$ - $(+)$-diethyl tartrate. ${ }^{3,4}$ Racemic standards of compounds $\mathbf{3 a - 3} \mathbf{m}$ were prepared as described in a previous communication. $^{5}$

General Procedure (A) for the synthesis of chiral phosphites. To a dry round-bottom flask with magnetic stir bar was added $4 \mathrm{~mL}$ dry THF, $\mathrm{PCl}_{3}$ (2.0 equiv), and triethylamine (3.0 equiv) at $0{ }^{\circ} \mathrm{C}$ via an ice bath. To this solution was added a solution of diol $(0.8$ mmol, 1 equiv. $)$ in $4 \mathrm{~mL}$ THF via cannula, dropwise, under argon at $0{ }^{\circ} \mathrm{C}$. The reaction was allowed to stir at the same temperature for $1 \mathrm{~h}$. To the resulting solution was added triethylamine (1.0 equiv) and $\mathrm{H}_{2} \mathrm{O}$ (1.0 
equiv) via a syringe at $0{ }^{\circ} \mathrm{C}$. The reaction mixture was allowed to warm to $25^{\circ} \mathrm{C}$ and stir for $1 \mathrm{~h}$. Solid triethylammonium chloride was removed by filtration through a pad of $\mathrm{MgSO}_{4}$ and the solvent was removed with a rotary evaporator. The crude product was purified by flash chromatography eluting with the indicated solvent system to afford the pure phosphite.

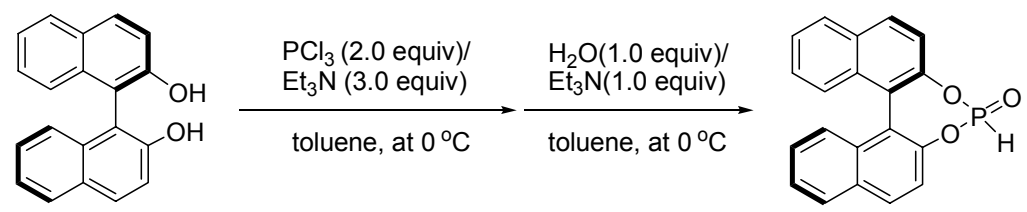

(R)-2,2'-binaphthyl phosphite (4b). The title compound was prepared according to General Procedure A using $1.14 \mathrm{~g}(4.0 \mathrm{mmol})$ of $(R)$-BINOL in $8 \mathrm{~mL}$ of toluene, $0.7 \mathrm{~mL}(8.0$ mmol) of $\mathrm{PCl}_{3}, 1.7 \mathrm{~mL}(12 \mathrm{mmol})$ of triethylamine, and $8 \mathrm{~mL}$ of toluene. After $1 \mathrm{~h}$ at $0{ }^{\circ} \mathrm{C}, 0.6 \mathrm{~mL}$ triethylamine and $72 \mu \mathrm{L}$ of $\mathrm{H}_{2} \mathrm{O}$ were added to the resulting mixture. The crude product was purified by recrystallization from toluene to afford $730 \mathrm{mg}(55 \%)$ of the product as white crystals (The product was decomposed on the silica gel column back to BINOL). Analytical data for title compound: ${ }^{6}{ }^{1} \mathbf{H}$ NMR $\left(400 \mathrm{MHz}, \mathrm{CDCl}_{3}\right) \delta 8.05(\mathrm{~d}, J=8.8 \mathrm{~Hz}, 2 \mathrm{H}), 7.97(\mathrm{~d}, J=8.0 \mathrm{~Hz}, 2 \mathrm{H})$, 7.70-7.30 (m, 8H), $7.30\left(\mathrm{~d}, J_{\mathrm{H}-\mathrm{P}}=732 \mathrm{~Hz}, 1 \mathrm{H}\right)$; TLC $\left(5: 1\right.$ hexanes/EtOAc) $\mathrm{R}_{f}$ 0.19. For ${ }^{1} \mathrm{H}$ NMR spectrum, see Appendix.

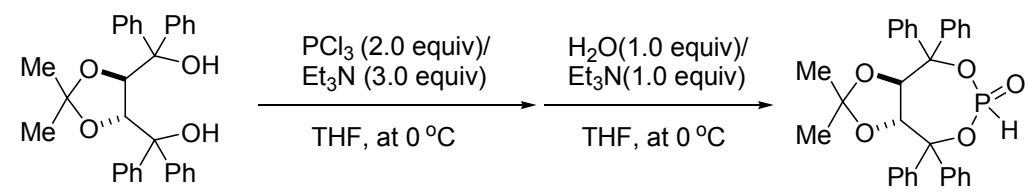

$(1 R, 7 R)$-9,9-dimethyl-4-hydrido-4-oxo-2,2,6,6-tetraphenyl-3,5,8,10-tetraoxa-4-phosphabicyclo[5.3.0]decane (4c). The title compound was prepared according to General Procedure A using $467 \mathrm{mg}(1.0 \mathrm{mmol})$ of $(4 R, 5 R)$-2,2-dimethyl-tetraphenyl-TADDOL in $5 \mathrm{~mL}$ of THF, 0.20 $\mathrm{mL}(2.2 \mathrm{mmol})$ of $\mathrm{PCl}_{3}, 0.42 \mathrm{~mL}(3.0 \mathrm{mmol})$ of triethylamine, and $5 \mathrm{~mL}$ of THF. After $1 \mathrm{~h}$ at $0{ }^{\circ} \mathrm{C}$, $0.2 \mathrm{~mL}$ triethylamine and $0.1 \mathrm{~mL}$ of $\mathrm{H}_{2} \mathrm{O}$ were added to the resulting mixture. The crude product was purified by flash chromatography with 3:1 hexanes/EtOAc to afford $454 \mathrm{mg}(89 \%)$ of the product as white crystals. Analytical data for title compound: ${ }^{7} \mathbf{H}$ NMR $\left(400 \mathrm{MHz}, \mathrm{CDCl}_{3}\right) \delta 7.60$ $(\mathrm{t}, J=7.6 \mathrm{~Hz}, 4 \mathrm{H}), 7.50-7.00(\mathrm{~m}, 16 \mathrm{H}), 7.08\left(\mathrm{~d}, J_{\mathrm{H}-\mathrm{P}}=724 \mathrm{~Hz}, 1 \mathrm{H}\right), 5.36(\mathrm{~d}, J=8.0 \mathrm{~Hz}, 1 \mathrm{H}), 5.21$ $(\mathrm{d}, J=8.0 \mathrm{~Hz}, 1 \mathrm{H}), 0.76(\mathrm{~s}, 3 \mathrm{H}), 0.57(\mathrm{~s}, 3 \mathrm{H}) ;{ }^{31} \mathbf{P}$ NMR $\left(162 \mathrm{MHz}, \mathrm{CDCl}_{3}\right) \delta-4.01\left(J_{\mathrm{H}-\mathrm{P}}=724\right.$ $\mathrm{Hz}$ ); TLC (3:1 hexanes/EtOAc) $\mathrm{R}_{f}$ 0.20. For ${ }^{1} \mathrm{H}$ NMR spectrum, see Appendix.

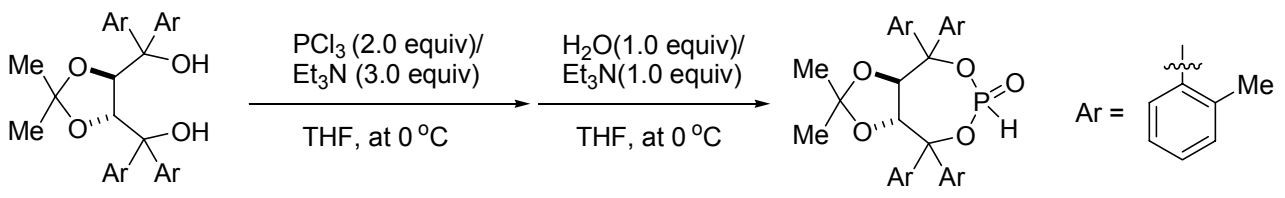

(1R,7R)-9,9-dimethyl-4-hydrido-4-oxo-2,2,6,6-tetra(2-methylphenyl)-3,5,8,10-tetraoxa-

4-phosphabicyclo[5.3.0]decane (4d). The title compound was prepared according to General Procedure A using $278 \mathrm{mg}(0.53 \mathrm{mmol})$ of ( $4 R, 5 R)$-2,2-dimethyl-tetra(2-methylphenyl)- TADDOL in $3 \mathrm{~mL}$ of THF, $92 \mu \mathrm{L}(1.0 \mathrm{mmol})$ of $\mathrm{PCl}_{3}, 0.18 \mathrm{~mL}(1.3 \mathrm{mmol})$ of triethylamine, and $3 \mathrm{~mL}$ of THF. After $1 \mathrm{~h}$ at $0{ }^{\circ} \mathrm{C}, 0.1 \mathrm{~mL}$ triethylamine and $15 \mu \mathrm{L}$ of $\mathrm{H}_{2} \mathrm{O}$ were added to the resulting mixture. The crude product was purified by flash chromatography with 4:1 hexanes/EtOAc to 
afford $265 \mathrm{mg}(88 \%)$ of the product as white crystals. Analytical data for title compound: ${ }^{1} \mathbf{H}$ NMR $\left(400 \mathrm{MHz}, \mathrm{CDCl}_{3}\right) \delta 8.17$ (broad singlet $1 \mathrm{H}$ ), 8.00-6.80 (broad multiplet, $\left.15 \mathrm{H}\right), 6.78\left(\mathrm{~d}, J_{\mathrm{H}-\mathrm{P}}\right.$ $=720 \mathrm{~Hz}, 1 \mathrm{H}), 5.90($ broad singlet $1 \mathrm{H}), 5.82($ broad singlet $1 \mathrm{H}), 1.97$ (broad singlet $12 \mathrm{H}), 1.56$ (broad singlet $3 \mathrm{H}$ ), 0.46 (broad singlet $3 \mathrm{H}$ ); peaks were noticeably broadened and difficult to integrate, likely due to slow rotation; ${ }^{31} \mathbf{P}$ NMR $\left(162 \mathrm{MHz}, \mathrm{CDCl}_{3}\right) \delta-5.99\left(J_{\mathrm{H}-\mathrm{P}}=720 \mathrm{~Hz}\right)$; TLC (3:1 hexanes/EtOAc) $\mathrm{R}_{f}$ 0.38. For ${ }^{1} \mathrm{H}$ NMR spectrum, see Appendix.

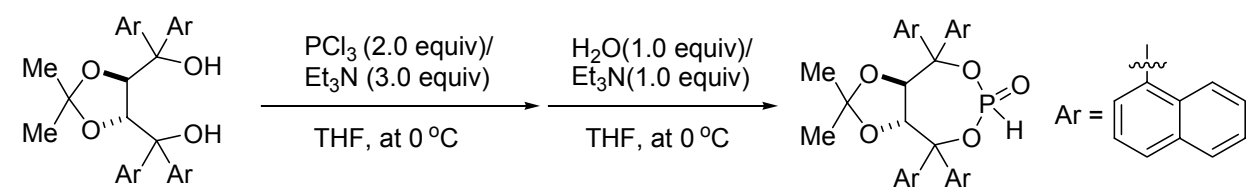

(1R,7R)-9,9-dimethyl-4-hydrido-4-oxo-2,2,6,6-tetra(2-naphthyl)-3,5,8,10-tetraoxa-4phosphabicyclo[5.3.0]decane (4e). The title compound was prepared according to General Procedure A using $688 \mathrm{mg}(1.0 \mathrm{mmol})$ of (4R,5R)-2,2-dimethyl-tetra(2-naphthyl)-TADDOL in 5 $\mathrm{mL}$ of THF, $0.2 \mathrm{~mL}$ (2.1 mmol) of $\mathrm{PCl}_{3}, 0.45 \mathrm{~mL}(3.1 \mathrm{mmol})$ of triethylamine, and $5 \mathrm{~mL}$ of THF. After $1 \mathrm{~h}$ at $0{ }^{\circ} \mathrm{C}, 0.15 \mathrm{~mL}$ triethylamine and $20 \mu \mathrm{L}$ of $\mathrm{H}_{2} \mathrm{O}$ were added to the resulting mixture. The crude product was purified by flash chromatography with 2:1 hexanes/EtOAc to afford 400 mg $(65 \%)$ of the product as white crystals. Analytical data for title compound: ${ }^{1} \mathbf{H}$ NMR (400 $\mathrm{MHz}, \mathrm{CDCl}_{3}$ ) $\delta$ 9.00-6.80 (m, 28H), 6.59 (broad doublet, 1H), 6.44 (broad doublet, 1H), 5.66 (one peak of doublet for H-P with the other obscured in the aromatic region, 1H), 1.21 (broad singlet, $3 \mathrm{H}$ ), -0.19 (broad singlet, $3 \mathrm{H}$ ); peaks were noticeably broadened and difficult to integrate, likely due to slow rotation; TLC (2:1 hexanes/EtOAc) $\mathrm{R}_{f}$ 0.30. For ${ }^{1} \mathrm{H}$ NMR spectrum, see Appendix.

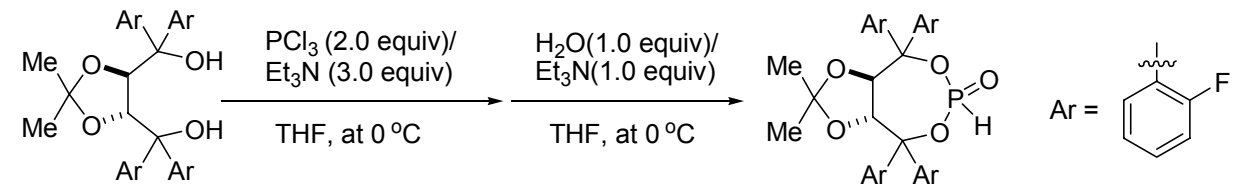

(-)-(1R,7R)-9,9-dimethyl-4-hydrido-4-oxo-2,2,6,6-tetra(2-fluorophenyl)-3,5,8,10-tetraoxa-

4-phosphabicyclo[5.3.0]decane (4f). The title compound was prepared according to General Procedure A using $2.6 \mathrm{~g}(4.8 \mathrm{mmol})$ of $(4 R, 5 R)$-2,2-dimethyl-tetra(2-fluorophenyl)-TADDOL in $30 \mathrm{~mL}$ of THF, $0.85 \mathrm{~mL}(9.6 \mathrm{mmol})$ of $\mathrm{PCl}_{3}, 2.0 \mathrm{~mL}$ (14 mmol) of triethylamine, and $30 \mathrm{~mL}$ of THF. After $1 \mathrm{~h}$ at $0{ }^{\circ} \mathrm{C}, 0.7 \mathrm{~mL}$ triethylamine and $0.1 \mathrm{~mL}$ of $\mathrm{H}_{2} \mathrm{O}$ were added to the resulting mixture. The crude product was purified by flash chromatography with 2:1 hexanes/EtOAc to afford $2.2 \mathrm{~g} \mathrm{(79 \% )} \mathrm{of} \mathrm{the} \mathrm{product} \mathrm{as} \mathrm{white} \mathrm{crystals.} \mathrm{Analytical} \mathrm{data} \mathrm{for} \mathrm{title} \mathrm{compound:} \mathrm{IR} \mathrm{(Nujol}$ mull, $\mathrm{cm}^{-1}$ ) 2939, 2902, 2855, 1608, 1583, 1456, 1377, 1279, 1228, 1171, 1122, 1103, 1082, 1020, 950, 920, 810, 762, 750, 721; ${ }^{1} \mathbf{H}$ NMR $\left(400 \mathrm{MHz}, \mathrm{CDCl}_{3}\right) \delta 8.11(\mathrm{t}, J=7.6 \mathrm{~Hz}, 1 \mathrm{H}), 7.76(\mathrm{t}, J=$ $7.6 \mathrm{~Hz}, 1 \mathrm{H}), 7.70-7.55(\mathrm{~m}, 2 \mathrm{H}), 7.50-7.15(\mathrm{~m}, 8 \mathrm{H}), 7.15-6.80(\mathrm{~m}, 4 \mathrm{H}), 6.98\left(\mathrm{~d}, J_{\mathrm{H}-\mathrm{P}}=748 \mathrm{~Hz}, 1 \mathrm{H}\right)$, $5.71(\mathrm{~d}, J=8.0 \mathrm{~Hz}, 1 \mathrm{H}), 5.51(\mathrm{~d}, J=8.0 \mathrm{~Hz}, 1 \mathrm{H}), 0.78(\mathrm{~s}, 3 \mathrm{H}), 0.71(\mathrm{~s}, 3 \mathrm{H}) ;{ }^{31} \mathbf{P} \mathbf{N M R}(162 \mathrm{MHz}$, $\left.\mathrm{CDCl}_{3}\right) \delta-3.23\left(J_{\mathrm{H}-\mathrm{P}}=748 \mathrm{~Hz}\right) ;$ TLC $\left(2: 1\right.$ hexanes/EtOAc) $\mathrm{R}_{f} 0.29 ; \mathrm{mp} 210-211{ }^{\circ} \mathrm{C} ;[\alpha]_{\mathrm{D}}{ }^{25}-215$ (c $=0.81, \mathrm{CH}_{2} \mathrm{Cl}_{2}$ ); Anal. Calcd. for $\mathrm{C}_{31} \mathrm{H}_{25} \mathrm{~F}_{4} \mathrm{O}_{5} \mathrm{P}: \mathrm{C}, 63.70 ; \mathrm{H}, 4.31$. Found: C, 63.55; H, 4.35; For ${ }^{1} \mathrm{H}$ NMR spectum, see Appendix. 


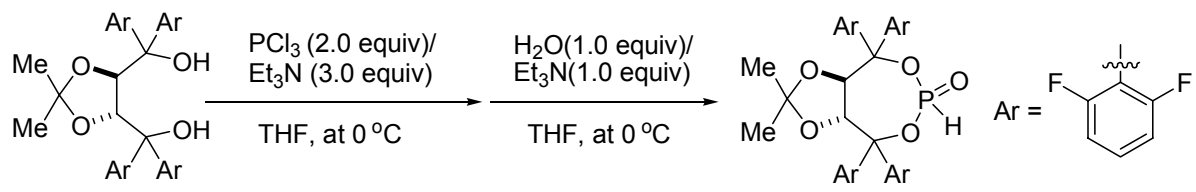

(1R,7R)-9,9-dimethyl-4-hydrido-4-oxo-2,2,6,6-tetra(2,6-difluorophenyl)-3,5,8,10-tetraoxa-

4-phosphabicyclo[5.3.0]decane (4g). The title compound was prepared according to General Procedure A using $210 \mathrm{mg}(0.34 \mathrm{mmol})$ of (4R,5R)-2,2-dimethyl-tetra(2,6-difluorophenyl)TADDOL in $3 \mathrm{~mL}$ of THF, $60 \mu \mathrm{L}(0.69 \mathrm{mmol})$ of $\mathrm{PCl}_{3}, 0.15 \mathrm{~mL}(1.0 \mathrm{mmol})$ of triethylamine, and $3 \mathrm{~mL}$ of THF. After $1 \mathrm{~h}$ at $0{ }^{\circ} \mathrm{C}, 50 \mu \mathrm{L}$ triethylamine and $10 \mu \mathrm{L}$ of $\mathrm{H}_{2} \mathrm{O}$ were added to the resulting mixture. The crude product was purified by flash chromatography with 1.5:1 hexanes/EtOAc to afford $120 \mathrm{mg}(55 \%)$ of the product as white crystals. Analytical data for title compound: ${ }^{1} \mathbf{H}$ NMR $\left(400 \mathrm{MHz}, \mathrm{CDCl}_{3}\right) \delta$ 7.40-7.20 (m, 4H), 7.10-6.80 (m, 8H), $6.82\left(\mathrm{~d}, J_{\mathrm{H}-\mathrm{P}}=740 \mathrm{~Hz}, 1 \mathrm{H}\right)$, $6.16(\mathrm{~d}, J=7.2 \mathrm{~Hz}, 1 \mathrm{H}), 5.89(\mathrm{~d}, J=7.2 \mathrm{~Hz}, 1 \mathrm{H}), 0.78(\mathrm{~s}, 3 \mathrm{H}), 0.71(\mathrm{~s}, 3 \mathrm{H}) ;{ }^{31} \mathbf{P}$ NMR $(162 \mathrm{MHz}$, $\left.\mathrm{CDCl}_{3}\right) \delta-7.60\left(J_{\mathrm{H}-\mathrm{P}}=740 \mathrm{~Hz}\right)$; TLC $\left(1.5: 1\right.$ hexanes/EtOAc) $\mathrm{R}_{f} 0.30$. For ${ }^{1} \mathrm{H}$ NMR spectum, see Appendix.

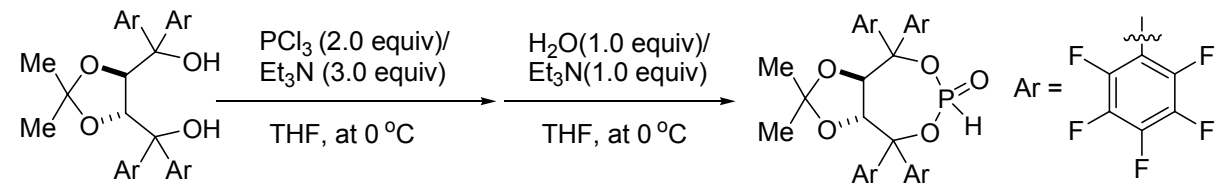

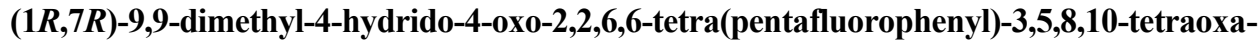

4-phosphabicyclo[5.3.0]decane (4h). The title compound was prepared according to General Procedure A using $205 \mathrm{mg}(0.24 \mathrm{mmol})$ of $(4 R, 5 R)$-2,2-dimethyl-tetra(pentafluorophenyl)TADDOL in $3 \mathrm{~mL}$ of THF, $42 \mu \mathrm{L}(0.47 \mathrm{mmol})$ of $\mathrm{PCl}_{3}, 0.10 \mathrm{~mL}(0.71 \mathrm{mmol})$ of triethylamine, and $3 \mathrm{~mL}$ of THF. After $1 \mathrm{~h}$ at $0{ }^{\circ} \mathrm{C}, 40 \mu \mathrm{L}$ triethylamine and $6 \mu \mathrm{L}$ of $\mathrm{H}_{2} \mathrm{O}$ were added to the resulting mixture. Crude $4 \mathbf{h}$ was used directly in the next reaction since it decomposed upon attempted purification. Analytical data for title compound: ${ }^{1} \mathbf{H}$ NMR $\left(400 \mathrm{MHz}, \mathrm{CDCl}_{3}\right) \delta 6.98\left(\mathrm{~d}, J_{\mathrm{H}-\mathrm{P}}=772\right.$ $\mathrm{Hz}, 1 \mathrm{H}), 6.03(\mathrm{~d}, J=8.0 \mathrm{~Hz}, 1 \mathrm{H}), 5.26(\mathrm{~d}, J=8.0 \mathrm{~Hz}, 1 \mathrm{H}), 1.24(\mathrm{~s}, 3 \mathrm{H}), 0.73$ (s, 3H) (doublet at $\delta$ 1.42 was a non-phosphorous-containing impurity); ${ }^{31} \mathbf{P} \mathbf{N M R}\left(162 \mathrm{MHz}, \mathrm{CDCl}_{3}\right) \delta-2.69\left(J_{\mathrm{H}-\mathrm{P}}=\right.$ $772 \mathrm{~Hz}$ ). For ${ }^{1} \mathrm{H}$ NMR spectrum, see Appendix.

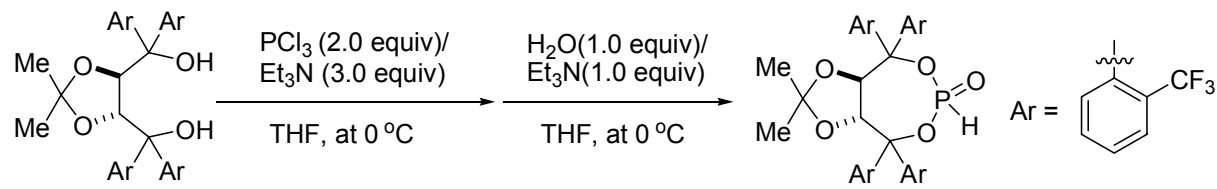

(1R,7R)-9,9-dimethyl-4-hydrido-4-oxo-2,2,6,6-tetra(2-trifluoromethylphenyl)-3,5,8,10tetraoxa-4-phosphabicyclo[5.3.0]decane (4i). The title compound was prepared according to General Procedure A using $254 \mathrm{mg}(0.34 \mathrm{mmol})$ of $(4 R, 5 R)$-2,2-dimethyltetra(2-trifluoromethylphenyl)-TADDOL in $3 \mathrm{~mL}$ of THF, $60 \mu \mathrm{L}(0.69 \mathrm{mmol})$ of $\mathrm{PCl}_{3}, 0.15 \mathrm{~mL}$ $(1.0 \mathrm{mmol})$ of triethylamine, and $3 \mathrm{~mL}$ of THF. After $1 \mathrm{~h}$ at $0{ }^{\circ} \mathrm{C}, 90 \mu \mathrm{L}$ triethylamine and $10 \mu \mathrm{L}$ of $\mathrm{H}_{2} \mathrm{O}$ were added to the resulting mixture. The crude product was purified by flash chromatography with $3: 1$ hexanes/EtOAc to afford $218 \mathrm{mg}(81 \%)$ of the product as white crystals. Analytical data for title compound: ${ }^{1} \mathbf{H}$ NMR $\left(400 \mathrm{MHz}, \mathrm{CDCl}_{3}\right) \delta 8.54(\mathrm{~d}, J=8.0 \mathrm{~Hz}, 1 \mathrm{H}), 8.35$ $(\mathrm{d}, J=8.4 \mathrm{~Hz}, 1 \mathrm{H}), 7.96(\mathrm{~d}, J=8.8 \mathrm{~Hz}, 1 \mathrm{H}), 7.89(\mathrm{~d}, J=8.0 \mathrm{~Hz}, 1 \mathrm{H}), 7.80-7.60(\mathrm{~m}, 6 \mathrm{H})$, 
7.55-7.20 (m, 6H), $7.01\left(\mathrm{~d}, J_{\mathrm{H}-\mathrm{P}}=740 \mathrm{~Hz}, 1 \mathrm{H}\right), 6.19(\mathrm{~d}, J=7.6 \mathrm{~Hz}, 1 \mathrm{H}), 5.21(\mathrm{~d}, J=7.6 \mathrm{~Hz}, 1 \mathrm{H})$, $0.05(\mathrm{~s}, 6 \mathrm{H}) ;{ }^{31} \mathbf{P}$ NMR $\left(162 \mathrm{MHz}, \mathrm{CDCl}_{3}\right) \delta 3.71\left(J_{\mathrm{H}-\mathrm{P}}=740 \mathrm{~Hz}\right)$; TLC $\left(3: 1\right.$ hexanes/EtOAc) $\mathrm{R}_{f}$ 0.21. For ${ }^{1} \mathrm{H}$ NMR spectrum, see Appendix.

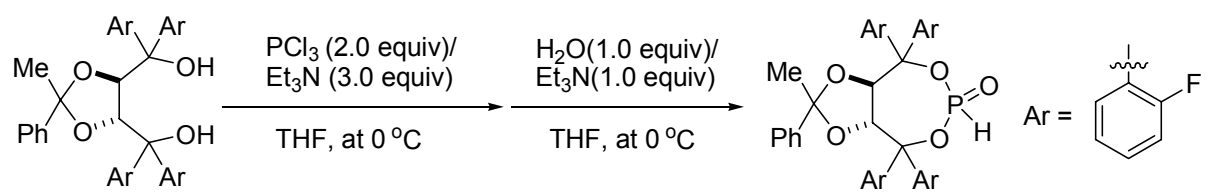

(1R,7R)-9-methyl-9-phenyl-4-hydrido-4-oxo-2,2,6,6-tetra(2-fluorophenyl)-3,5,8,10tetraoxa-4-phosphabicyclo[5.3.0]decane $(\mathbf{4 j})$. The title compound was prepared according to General Procedure A using $100 \mathrm{mg} \quad(0.17 \quad \mathrm{mmol}) \quad(4 R, 5 R)$-2-methyl-2-phenyl-tetra(2-fluoro-phenyl)-TADDOL in $0.6 \mathrm{~mL}$ THF, $29 \mu \mathrm{L}(0.33 \mathrm{mmol}) \mathrm{PCl}_{3}, 93 \mu \mathrm{L}(0.67 \mathrm{mmol})$ triethylamine and $0.9 \mathrm{~mL}$ of THF. After $1 \mathrm{~h}$ at $0{ }^{\circ} \mathrm{C}, 0.024 \mathrm{~mL}$ triethylamine and $3 \mu \mathrm{L} \mathrm{H}_{2} \mathrm{O}$ were added to the resulting mixture. The crude product was purified by flash chromatography with 10:3 hexanes/EtOAc to afford $45 \mathrm{mg}(42 \%)$ of the product as white crystals. Analytical data for title compound: ${ }^{1} \mathbf{H}$ NMR $\left(400 \mathrm{MHz}, \mathrm{CDCl}_{3}\right) \delta 8.14(\mathrm{dt}, J=7.7 \mathrm{~Hz}, J=1.8 \mathrm{~Hz}, 1 \mathrm{H}), 7.86-7.75$ (m, 4H), 7.74-7.68 (m, 2H), 7.63 (t, $J=7.7 \mathrm{~Hz}, 1 \mathrm{H}), 7.48-7.22(\mathrm{~m}, 12 \mathrm{H}), 7.19-6.85(\mathrm{~m}, 20 \mathrm{H})$, $6.97\left(\mathrm{~d}, J_{\mathrm{H}-\mathrm{P}}=748.5 \mathrm{~Hz}, 1 \mathrm{H}\right), 6.93\left(\mathrm{~d}, J_{\mathrm{H}-\mathrm{P}}=744.4 \mathrm{~Hz}, 1 \mathrm{H}\right), 6.62-6.57(\mathrm{~m}, 1 \mathrm{H}), 6.54-6.49(\mathrm{~m}, 1 \mathrm{H})$, 5.84-5.79 (m, 2H), 5.63-5.60 (m, 2H), 0.99 (s, 3H), 0.93 (s, 3H); ${ }^{31} \mathbf{P}$ NMR $\left(162 \mathrm{MHz}, \mathrm{CDCl}_{3}\right) \delta$ $-2.25,-3.45$; TLC (7:3 hexanes/EtOAc) $\mathrm{R}_{f}$ 0.21. For ${ }^{1} \mathrm{H}$ NMR spectrum, see Appendix.

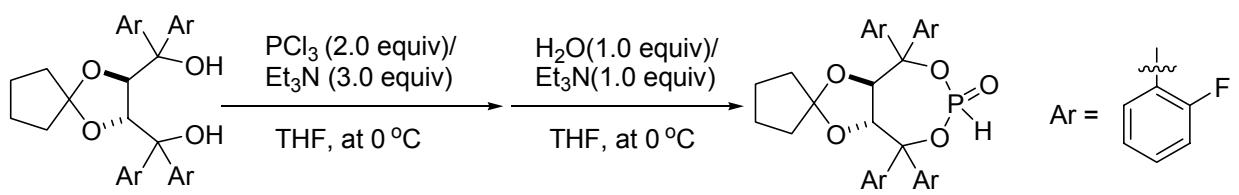

(2R,3R)-(2,3-Di-(1,1-di-(2-fluorophenyl)meth-1-yl)-1,4-dioxaspiro[4.4]nonane)phosphite (4k). The title compound was prepared according to General Procedure A using $305 \mathrm{mg}(0.48$ $\mathrm{mmol}) \quad$ of $\{(2 R, 3 R)-3$-[bis-(2-fluorophenyl)-hydroxymethyl]-1,4-dioxaspiro[4.4]non-2-yl $\}$-bis(2-fluorophenyl)-methanol in $6 \mathrm{~mL}$ of THF, $78 \mu \mathrm{L}(0.89 \mathrm{mmol})$ of $\mathrm{PCl}_{3}, 0.19 \mathrm{~mL}(1.34 \mathrm{mmol})$ of triethylamine, and $6 \mathrm{~mL}$ of THF. After $1 \mathrm{~h}$ at $0{ }^{\circ} \mathrm{C}, 70 \mu \mathrm{L}$ triethylamine and $10 \mu \mathrm{L}$ of $\mathrm{H}_{2} \mathrm{O}$ were added to the resulting mixture. The crude product was purified by flash chromatography with 2.5:1 hexanes/EtOAc to afford $236 \mathrm{mg}(72 \%)$ of the product as white crystals. Analytical data for title compound: ${ }^{1} \mathbf{H}$ NMR $\left(400 \mathrm{MHz}, \mathrm{CDCl}_{3}\right) \delta 8.07(\mathrm{dt}, J=7.6 \mathrm{~Hz}, J=1.6 \mathrm{~Hz}, 1 \mathrm{H}), 7.75(\mathrm{dt}, J=$ $8.0 \mathrm{~Hz}, J=1.6 \mathrm{~Hz}, 1 \mathrm{H}), 7.63-7.56(\mathrm{~m}, 2 \mathrm{H}), 7.45-7.18(\mathrm{~m}, 8 \mathrm{H}), 7.12-6.87(\mathrm{~m}, 4 \mathrm{H}), 6.98\left(\mathrm{~d}, J_{\mathrm{H}-\mathrm{P}}=\right.$ $748 \mathrm{~Hz}, 1 \mathrm{H}), 5.67(\mathrm{~d}, J=8.0 \mathrm{~Hz}, 1 \mathrm{H}), 5.41(\mathrm{~d}, J=8.0 \mathrm{~Hz}, 1 \mathrm{H}), 1.50-1.33(\mathrm{~m}, 4 \mathrm{H}), 1.33-1.20(\mathrm{~m}$, $1 \mathrm{H}), 1.11-0.95(\mathrm{~m}, 2 \mathrm{H}), 0.93-0.82(\mathrm{~m}, 1 \mathrm{H}) ;{ }^{31} \mathbf{P}$ NMR $\left(162 \mathrm{MHz}, \mathrm{CDCl}_{3}\right) \delta-2.78\left(J_{\mathrm{H}-\mathrm{P}}=748 \mathrm{~Hz}\right)$; TLC (3:1 hexanes/EtOAc) $R_{f}$ 0.21. For ${ }^{1} \mathrm{H}$ NMR spectrum, see Appendix.

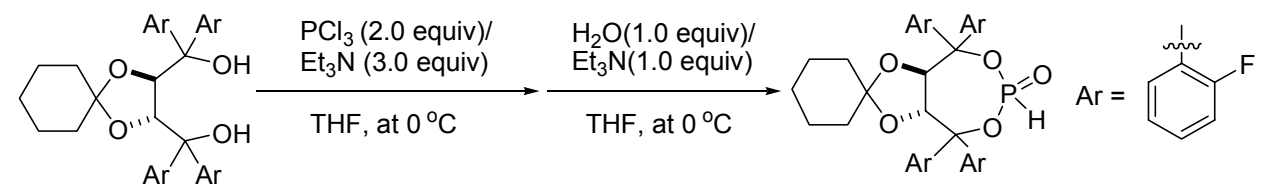

(2R,3R)-(2,3-Di-(1,1-di-(2-fluorophenyl)meth-1-yl)-1,4-dioxaspiro[4.5]decane)phosphite

(4I). The title compound was prepared according to General Procedure A using $200 \mathrm{mg}(0.35$ 
mmol) $\quad\{(2 R, 3 R)-3$-[Bis-(2-fluorophenyl)-hydroxymethyl]-1,4-dioxaspiro[4.5]dec-2-yl $\}$-bis(2-fluorophenyl)-methanol in $1.5 \mathrm{~mL}$ THF, $60 \mu \mathrm{L}(0.7 \mathrm{mmol}) \mathrm{PCl}_{3}, 0.2 \mathrm{~mL}(1.4 \mathrm{mmol})$ triethylamine, and $2.0 \mathrm{~mL}$ of THF. After $1 \mathrm{~h}$ at $0{ }^{\circ} \mathrm{C}, 96 \mu \mathrm{L}$ triethylamine and $6 \mu \mathrm{L} \mathrm{H}_{2} \mathrm{O}$ were added to the resulting mixture. The crude product was purified by flash chromatography with 10:3 hexanes/EtOAc to afford $86 \mathrm{mg}(40 \%)$ of the product as a pale yellow crystal. Analytical data for title compound: ${ }^{1} \mathbf{H}$ NMR $\left(400 \mathrm{MHz}, \mathrm{CDCl}_{3}\right) \delta 8.10(\mathrm{dt}, J=7.9 \mathrm{~Hz}, J=1.8 \mathrm{~Hz}, 1 \mathrm{H})$, 7.76 (broad triplet, $J=7.8 \mathrm{~Hz}, 1 \mathrm{H}$ ), 7.67 (dt, $J=7.7 \mathrm{~Hz}, J=1.2 \mathrm{~Hz}, 1 \mathrm{H}$ ), 7.60 (broad triplet, $J=$ $6.6 \mathrm{~Hz}, 1 \mathrm{H}), 7.45-7.24(\mathrm{~m}, 8 \mathrm{H}), 7.09-7.02(\mathrm{~m}, 2 \mathrm{H}), 6.96\left(\mathrm{~d}, J_{\mathrm{H}-\mathrm{P}}=747.8 \mathrm{~Hz}, 1 \mathrm{H}\right), 6.93-6.85(\mathrm{~m}$, 2H), $5.63(\mathrm{~d}, J=8.0 \mathrm{~Hz}, 1 \mathrm{H}), 5.46(\mathrm{~d}, J=8.0 \mathrm{~Hz}, 1 \mathrm{H}), 1.31-1.26(\mathrm{~m}, 4 \mathrm{H}), 1.19-1.16(\mathrm{~m}, 2 \mathrm{H})$, 0.88-0.68 (m, 4H); ${ }^{31} \mathbf{P}$ NMR (162 MHz, $\left.\mathrm{CDCl}_{3}\right) \delta-3.39$; TLC (7:3 hexanes/EtOAc) $\mathrm{R}_{\mathrm{f}} 0.29$. For ${ }^{1} \mathrm{H}$ NMR spectrum, see Appendix.

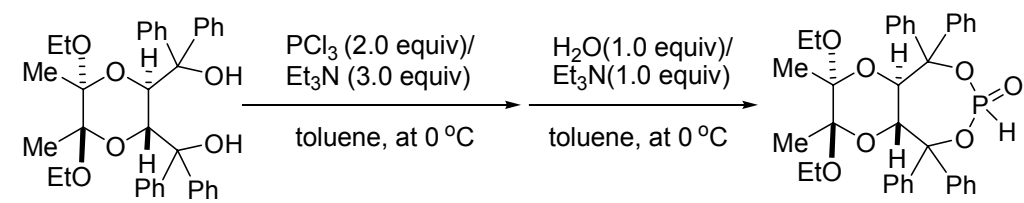

$(1 R, 7 R, 9 R, 10 R)-9,10$-diethoxy-9,10-dimethyl-4-hydrido-4-oxo-2,2,6,6-tetraphenyl-3,5,

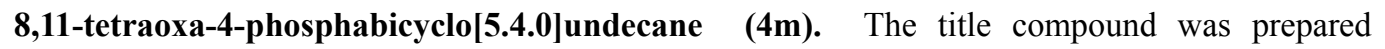
according to General Procedure A using $200 \mathrm{mg}(0.32 \mathrm{mmol})(2 R, 3 R, 5 R, 6 R)$-5,6-diethoxy-2,3bis(hydroxydiphenylmethyl)-5,6-dimethyl-1,4-dioxane ${ }^{8,9}$ in $1.5 \mathrm{~mL}$ toluene, $37 \mu \mathrm{L}(0.42 \mathrm{mmol})$ $\mathrm{PCl}_{3}, 0.11 \mathrm{~mL}(0.77 \mathrm{mmol})$ triethylamine, and $1.0 \mathrm{~mL}$ of toluene. After $2 \mathrm{~h}$ at $0{ }^{\circ} \mathrm{C}, 50 \mu \mathrm{L}$ triethylamine and $6 \mu \mathrm{L} \mathrm{H}_{2} \mathrm{O}$ were added to the resulting mixture. The crude product was purified by flash chromatography with 10:3 hexanes/EtOAc to afford $124 \mathrm{mg}(64 \%)$ of the product as white crystals. Analytical data for title compound: ${ }^{1} \mathbf{H}$ NMR $\left(400 \mathrm{MHz}, \mathrm{CDCl}_{3}\right) \delta 8.15-8.12$ $(\mathrm{m}, 2 \mathrm{H}), 8.01-7.98(\mathrm{~m}, 2 \mathrm{H}), 7.42-7.40(\mathrm{~m}, 6 \mathrm{H}), 7.20-7.15(\mathrm{~m}, 6 \mathrm{H}), 7.07-7.02(\mathrm{~m}, 4 \mathrm{H}), 6.78\left(\mathrm{~d}, J_{\mathrm{H}-\mathrm{P}}\right.$ $=733.5 \mathrm{~Hz}, 1 \mathrm{H}), 4.92\left(\mathrm{AB}, J_{\mathrm{AB}}=10.6 \mathrm{~Hz}, 2 \mathrm{H}\right), 2.95\left(\mathrm{ABX}, J_{\mathrm{AB}}=8.9 \mathrm{~Hz}, J_{\mathrm{AX}}=7.0 \mathrm{~Hz}, 2 \mathrm{H}\right), 2.15$ (dq, $J=8.8 \mathrm{~Hz}, J=7.1 \mathrm{~Hz}, 1 \mathrm{H}), 1.97$ (dq, $J=8.8 \mathrm{~Hz}, J=7.1 \mathrm{~Hz}, 1 \mathrm{H}), 1.11(\mathrm{~s}, 3 \mathrm{H}), 1.10$ (s, 3H), $1.08(\mathrm{t}, J=7.0 \mathrm{~Hz}, 3 \mathrm{H}), 0.96$ (t, $J=7.0 \mathrm{~Hz}, 3 \mathrm{H}) ; \quad{ }^{31} \mathbf{P}$ NMR $\left(162 \mathrm{MHz}, \mathrm{CDCl}_{3}\right) \quad \delta-2.41 ; \quad$ TLC (7:3 hexanes/EtOAc) $\mathrm{R}_{f}$ 0.14. For ${ }^{1} \mathrm{H}$ NMR spectrum, see Appendix.

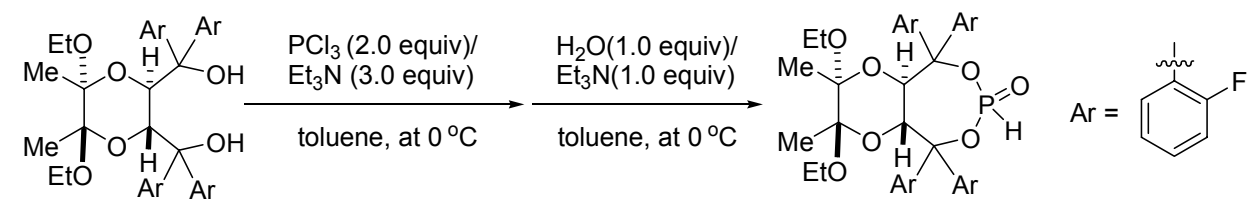

$(1 R, 7 R),(9 R, 10 R)-9,10$-diethoxy-9,10-dimethyl-4-hydrido-4-oxo-2,2,6,6-tetra(2-fluorophenyl)-3,5,8,11-tetraoxa-4-phosphabicyclo[5.4.0]undecane (4n): The title compound was prepared according to General Procedure A using $150 \mathrm{mg}(0.14 \mathrm{mmol})$ (2R,3R,5R,6R)-5,6-diethoxy-2,3-bis[hydroxydi(2-fluoro-phenyl)methyl]-5,6-dimethyl-1,4-dioxane ${ }^{8,9}$ in $1.5 \mathrm{~mL}$ toluene, $41 \mu \mathrm{L}(0.47 \mathrm{mmol}) \mathrm{PCl}_{3}, 0.131 \mathrm{~mL}(0.94 \mathrm{mmol})$ triethylamine and $1.0 \mathrm{~mL}$ of toluene. After $1 \mathrm{~h}$ at $0{ }^{\circ} \mathrm{C}, 30 \mu \mathrm{L}$ triethylamine and $4 \mu \mathrm{L} \mathrm{H}_{2} \mathrm{O}$ were added to the resulting mixture. The crude product was purified by flash chromatography with 7:3 hexanes/EtOAc to afford $83 \mathrm{mg}$ (52\%) of product as white crystals. Analytical data for title compound: ${ }^{1} \mathbf{H}$ NMR (400 MHz, $\left.\mathrm{CDCl}_{3}\right) \delta 8.70-8.64(\mathrm{~m}, 1 \mathrm{H}) 8.60$ (broad triplet, $\left.J=8.0 \mathrm{~Hz}, 1 \mathrm{H}\right) 7.59-6.40(\mathrm{~m}, 14 \mathrm{H}) 6.68\left(\mathrm{~d}, J_{\mathrm{H}-\mathrm{P}}\right.$ $=737.8 \mathrm{~Hz}, 1 \mathrm{H}) 5.70-4.60(\mathrm{~m}, 2 \mathrm{H}) 3.07-2.98(\mathrm{~m}, 2 \mathrm{H}) 2.30-1.95(\mathrm{~m}, 2 \mathrm{H}) 1.25-0.88(\mathrm{~m}, 12 \mathrm{H})$ 
peaks were noticeably broadened and difficult to integrate, likely due to slow rotation; ${ }^{31} \mathbf{P}$ NMR $\left(162 \mathrm{MHz}, \mathrm{CDCl}_{3}\right) \delta-3.61$; TLC (7:3 hexanes/EtOAc) $\mathrm{R}_{f}$ 0.11. For ${ }^{1} \mathrm{H}$ NMR spectrum, see Appendix.

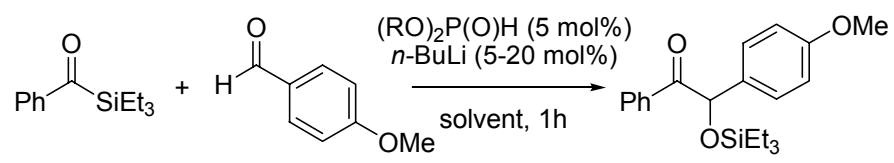

Enantioselective catalyst screen for the reaction between benzoyl triethylsilane and $p$-anisaldehyde. All subsequent manipulations were performed in a dry box to exclude moisture. A flame-dried vial with a magnetic stir bar was charged with $0.1 \mathrm{mmol}$ of acylsilane, aldehyde (1.2 equiv), phosphite ( 0.05 equiv) and $2 \mathrm{~mL}$ of solvent (THF, $\mathrm{Et}_{2} \mathrm{O}$, toluene or dioxane). After the mixture was cooled to $-30{ }^{\circ} \mathrm{C}$ in the freezer, $\mathrm{n}$-BuLi (0.05-0.2 equiv) was added dropwise via a syringe. The reaction was allowed to warm to $25^{\circ} \mathrm{C}$ and stir for $1 \mathrm{~h}$. After the reaction vial was taken out of the dry box, the solvent was removed with a rotary evaporator. The conversion of each reaction was checked by ${ }^{1} \mathrm{H}$ NMR analysis of the crude product. Each reaction was filtered through a pad of $\mathrm{SiO}_{2}$ with the aid of 5:1 hexanes/EtOAc and the combined portions were concentrated. Enantiomeric excesses were determined by CSP-SFC analysis ((S,S)-Whelk-O1, 1.0\% MeOH, 2.0 $\left.\mathrm{mL} / \mathrm{min}, 200 \mathrm{psi}, 40^{\circ} \mathrm{C}, 240 \mathrm{~nm}, t_{\mathrm{r}-\text { major }} 11.8 \mathrm{~min}, t_{\mathrm{r}-\text { minor }} 10.3 \mathrm{~min}\right)$.

General procedure (B) for the reaction of acylsilanes with aldehydes. A flame-dried round-bottom flask with a magnetic stir bar was charged with $0.5 \mathrm{mmol}$ of acylsilane, aldehyde (1.5 equiv) and phosphite $\mathbf{4 f}(0.05-0.2$ equiv) in the dry box. The flask was sealed with a septum and was brought out of the dry box. Under $\mathrm{Ar}, 8 \mathrm{~mL}$ of THF was added via a syringe. At $0{ }^{\circ} \mathrm{C}$ $\mathrm{n}$-BuLi (0.2-0.4 equiv) was added dropwise via a syringe. After the ice-bath was removed, the reaction was stirred under $\mathrm{Ar}$ for $0.5 \mathrm{~h}$ (monitored by TLC). The solvent was removed with a rotary evaporator and the crude product was purified by flash chromatography, eluting with the indicated solvent system to afford the pure silyl-protected benzoin product.

Deprotection of silyloxy ketones to corresponding hydroxy ketones. A round-bottom flask with a magnetic stir bar was charged with $0.2 \mathrm{mmol}$ of the pure silyloxy ketone. $10 \mathrm{~mL}$ of $\mathrm{MeOH}$ and $10 \mathrm{~mL} \mathrm{HCl}(1 \mathrm{M}$ aqueous solution) were added and the mixture was stirred for $10 \mathrm{~min}$ at $25{ }^{\circ} \mathrm{C}$ before $15 \mathrm{~mL} \mathrm{Et}_{2} \mathrm{O}$ was added to the flask. The organic layer was separated and the aqueous layer was extracted with two $15 \mathrm{~mL}$ portions of $\mathrm{Et}_{2} \mathrm{O}$. The organic extracts were combined, dried $\left(\mathrm{MgSO}_{4}\right)$, and the solvent was removed with a rotary evaporator. The product was purified by flash chromatography, eluting with the indicated solvent system to afford the pure benzoin product.

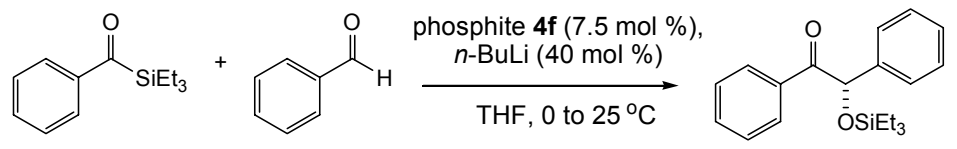

S-(-)-1,2-diphenyl-2-triethylsilyloxy-ethanone (3a). The title compound was prepared according to General Procedure B using $107 \mathrm{mg}(0.49 \mathrm{mmol})$ of acylsilane, $78 \mu \mathrm{L}(0.77 \mathrm{mmol})$ of benzaldehyde, $22 \mathrm{mg}(0.036 \mathrm{mmol})$ of phosphite $4 \mathbf{f}, 120 \mu \mathrm{L}(0.19 \mathrm{mmol})$ of $n$-BuLi $(1.6 \mathrm{M}$ in hexanes), and $8 \mathrm{~mL}$ of THF. After $0.5 \mathrm{~h}$ from $0{ }^{\circ} \mathrm{C}$ to $25{ }^{\circ} \mathrm{C}$, the crude product was purified by 
flash chromatography with 35:1 hexanes/EtOAc to afford $140 \mathrm{mg}(89 \%)$ of the product as a clear oil in $85 \%$ ee as determined by CSP-SFC analysis (Chiralpak AD, $0.5 \% \mathrm{MeOH}, 1.5 \mathrm{~mL} / \mathrm{min}, 150$ psi, $40{ }^{\circ} \mathrm{C}, 240 \mathrm{~nm}, t_{\mathrm{r}-\text { major }} 18.2 \mathrm{~min}, t_{\mathrm{r}-\text { minor }} 17.0 \mathrm{~min}$ ). Spectral data matched that reported previously. ${ }^{5}[\alpha]_{\mathrm{D}}{ }^{25}-8.7\left(\mathrm{c}=1.5, \mathrm{CH}_{2} \mathrm{Cl}_{2}\right)$. CSP-SFC chromatograms for both racemic and $85 \%$ ee samples are shown below:
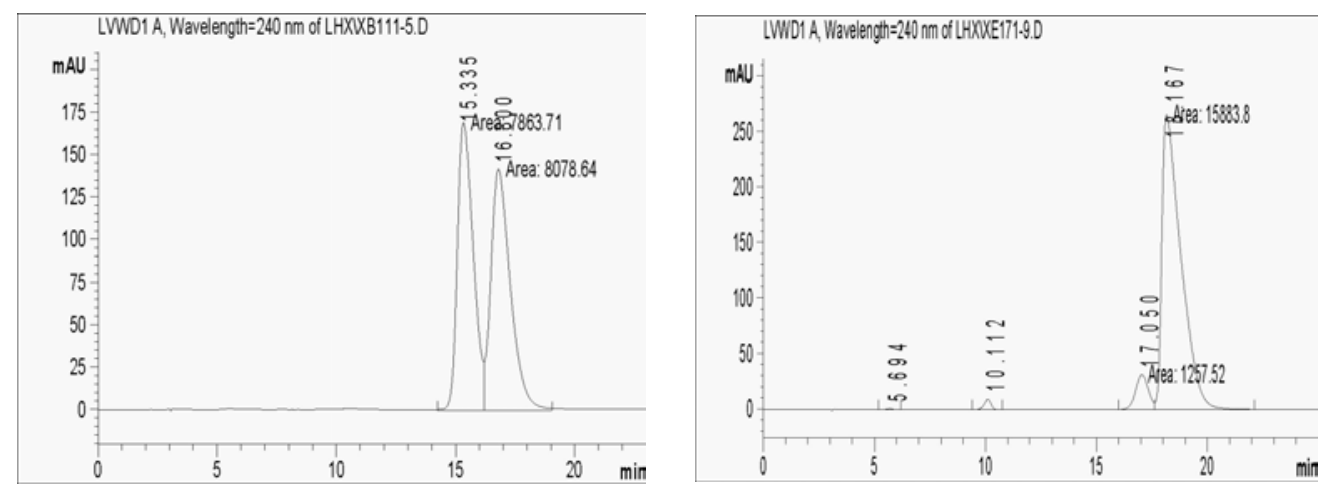

Deprotection of 3a. $15 \mathrm{~mL}$ of $\mathrm{MeOH}$ and $15 \mathrm{~mL} \mathrm{HCl}$ (1M aqueous solution) were added to a flask containing $177 \mathrm{mg}$ pure silyloxy ketone and the mixture was stirred for $10 \mathrm{~min}$ at $25^{\circ} \mathrm{C}$. The crude product was purified by flash chromatography with 4:1 hexanes/EtOAc to afford 107 $\mathrm{mg}(93 \%)$ of the corresponding hydroxy ketone product as white crystals. Analytical data for $S$-(+)-1,2-diphenyl-2-hydroxy-ethanone: ${ }^{1} \mathbf{H}$ NMR $\left(400 \mathrm{MHz}, \mathrm{CDCl}_{3}\right) \delta 7.92(\mathrm{dd}, J=8.4 \mathrm{~Hz}, 1.2$ $\mathrm{Hz}, 2 \mathrm{H}), 7.52$ (dt, $J=7.6 \mathrm{~Hz}, 0.8 \mathrm{~Hz}, 1 \mathrm{H}), 7.39$ (t, $J=8.0 \mathrm{~Hz}, 2 \mathrm{H}), 7.36-7.24(\mathrm{~m}, 5 \mathrm{H}), 5.96$ (d, $J=$ $6.0 \mathrm{~Hz}, 1 \mathrm{H}), 4.56(\mathrm{~d}, J=6.0 \mathrm{~Hz}, 1 \mathrm{H}) ;{ }^{13} \mathbf{C}$ NMR $\left(100 \mathrm{MHz}, \mathrm{CDCl}_{3}\right) \delta 198.9,139.0,133.8,133.6$, 129.1, 129.1, 128.6, 128.5, 127.7, 76.2; TLC (5:1 hexanes/EtOAc) $\mathrm{R}_{f} 0.19 ; \mathrm{mp} 122-124{ }^{\circ} \mathrm{C} ;[\alpha]_{\mathrm{D}}$ ${ }^{25}+86\left(\mathrm{c}=1.0, \mathrm{Me}_{2} \mathrm{CO}\right)\left(\right.$ Lit.: $[\alpha]_{\mathrm{D}}{ }^{25}+49\left(\mathrm{c}=0.91, \mathrm{Me}_{2} \mathrm{CO}, 43 \%\right.$ ee $)$ for $(S)$ configuration $) .{ }^{10}$

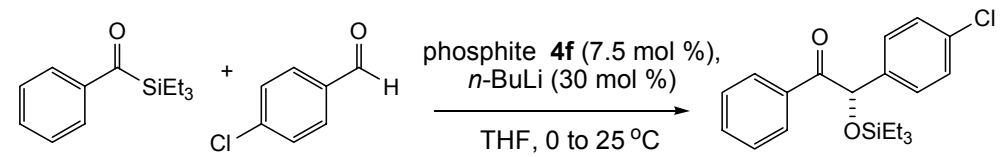

$S$-(-)-1-phenyl-2-(4-chlorophenyl)-2-triethylsilyloxy-ethanone (3b). The title compound was prepared according to General Procedure B using $107 \mathrm{mg}(0.49 \mathrm{mmol})$ of acylsilane, $103 \mathrm{mg}(0.73 \mathrm{mmol})$ of $p$-chlorobenzaldehyde, $22 \mathrm{mg}(0.036 \mathrm{mmol})$ of phosphite $4 \mathbf{f}, 91$ $\mu \mathrm{L}(0.14 \mathrm{mmol})$ of $n$-BuLi (1.6 M in hexanes), and $8 \mathrm{~mL}$ of THF. After $0.5 \mathrm{~h}$ from $0{ }^{\circ} \mathrm{C}$ to $25^{\circ} \mathrm{C}$, the crude product was purified by flash chromatography with 40:1 hexanes/EtOAc to afford 138 $\mathrm{mg}(79 \%)$ of the product as a clear oil in 79\% ee as determined by CSP-SFC analysis (Chiralcel OD-H, $0.5 \% \mathrm{MeOH}, 1.5 \mathrm{~mL} / \mathrm{min}, 150 \mathrm{psi}, 40{ }^{\circ} \mathrm{C}, 240 \mathrm{~nm}, t_{\mathrm{r}-\text { major }} 17.8 \mathrm{~min}, t_{\mathrm{r}-\text { minor }} 15.8 \mathrm{~min}$ ). Spectral data matched that reported previously. ${ }^{5}[\alpha]_{\mathrm{D}}{ }^{25}-33\left(\mathrm{c}=2.5, \mathrm{CH}_{2} \mathrm{Cl}_{2}\right)$. CSP-SFC chromatograms for both racemic and 79\% ee samples are shown below: 

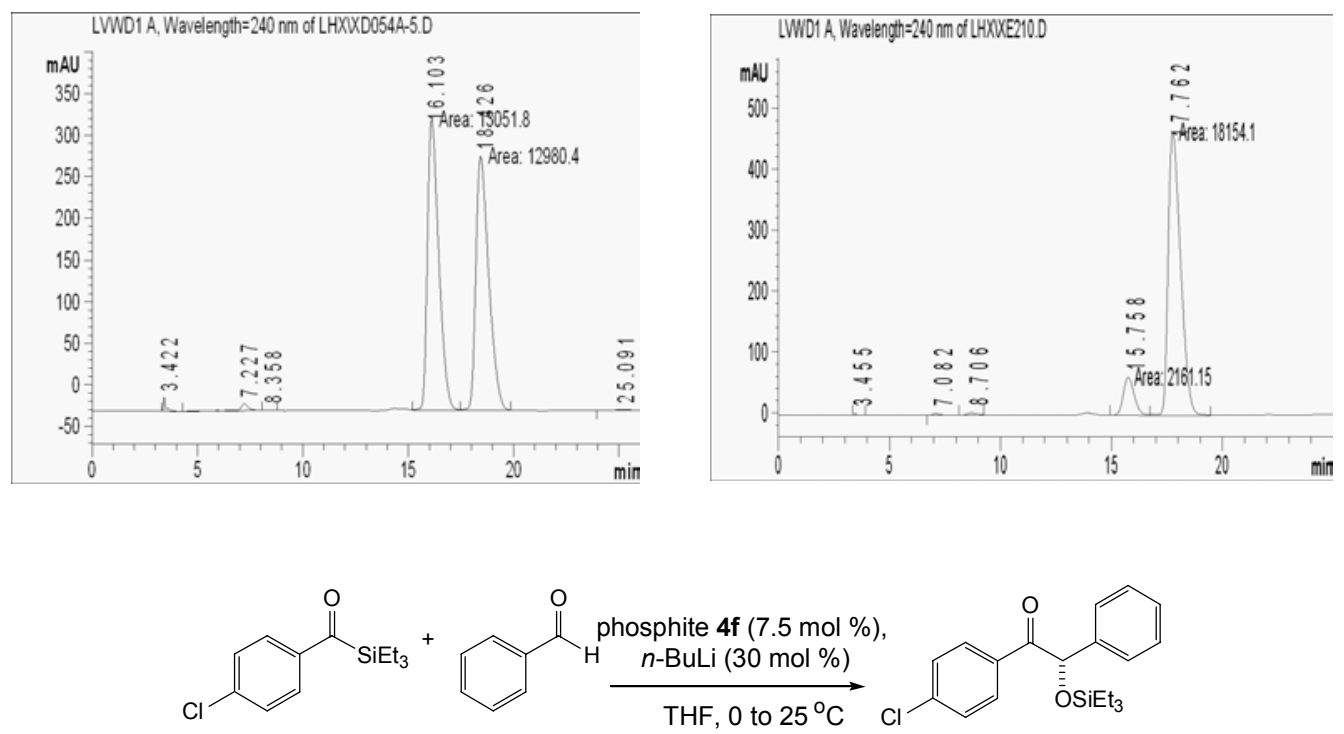

S-(-)-1-(4-chlorophenyl)-2-phenyl-2-triethylsilyloxy-ethanone (3c). The title compound was prepared according to General Procedure B using $105 \mathrm{mg}(0.41 \mathrm{mmol})$ of acylsilane, $63 \mu \mathrm{L}$ $(0.62 \mathrm{mmol})$ of benzaldehyde, $18 \mathrm{mg}(0.031 \mathrm{mmol})$ of phosphite $4 \mathbf{f}, 80 \mu \mathrm{L}(0.12 \mathrm{mmol})$ of $n$-BuLi (1.6 $\mathrm{M}$ in hexanes), and $8 \mathrm{~mL}$ of THF. After $0.5 \mathrm{~h}$ from $0{ }^{\circ} \mathrm{C}$ to $25{ }^{\circ} \mathrm{C}$, the crude product was purified by flash chromatography with $40: 1$ hexanes/EtOAc to afford $128 \mathrm{mg}(86 \%)$ of the product as a clear oil in $89 \%$ ee as determined by CSP-SFC analysis (Chiralcel OD-H, 0.5\% $\left.\mathrm{MeOH}, 1.5 \mathrm{~mL} / \mathrm{min}, 150 \mathrm{psi}, 40{ }^{\circ} \mathrm{C}, 240 \mathrm{~nm}, t_{\mathrm{r}-\text { major }} 14.2 \mathrm{~min}, t_{\mathrm{r}-\text { minor }} 16.1 \mathrm{~min}\right)$. Spectral data matched that reported previously. ${ }^{5}[\alpha]_{\mathrm{D}}{ }^{25}-33\left(\mathrm{c}=0.45, \mathrm{CH}_{2} \mathrm{Cl}_{2}\right)$. CSP-SFC chromatograms for both racemic and $89 \%$ ee samples are shown below:
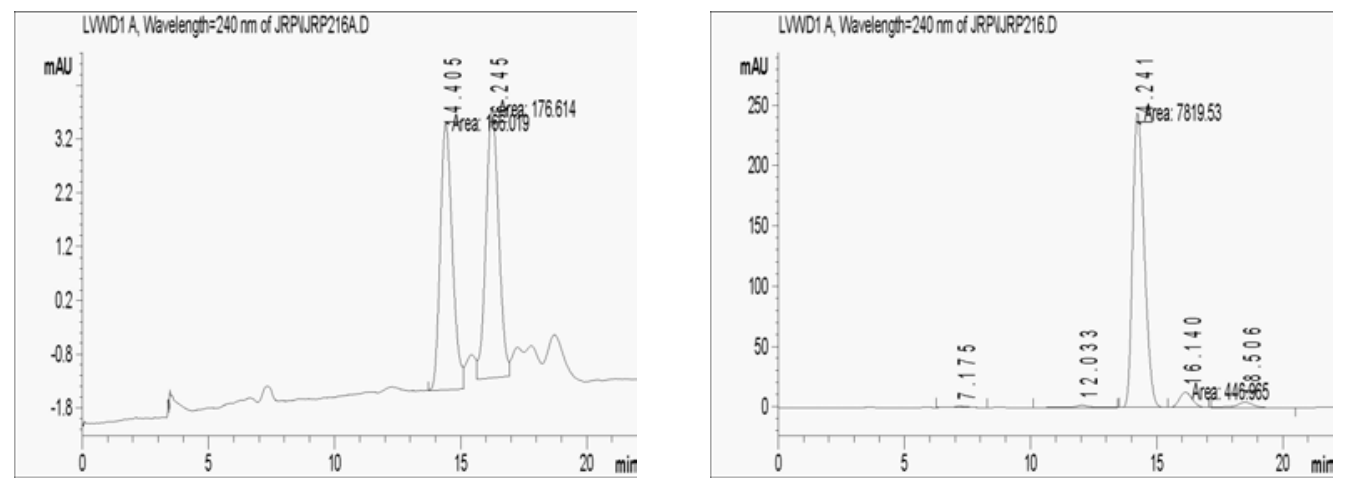

Deprotection of 3c. $10 \mathrm{~mL}$ of $\mathrm{MeOH}$ and $10 \mathrm{~mL} \mathrm{HCl}(1 \mathrm{M}$ aqueous solution) were added to a flask containing $110 \mathrm{mg}$ pure silyloxy ketone and the mixture was stirred for $10 \mathrm{~min}$ at $25^{\circ} \mathrm{C}$. The crude product was purified by flash chromatography with 4:1 hexanes/EtOAc to afford $70 \mathrm{mg}$ $(93 \%)$ of the corresponding hydroxy ketone product as white crystals. Analytical data for $S$-(+)-1-(4-chlorophenyl)-2-hydroxy-2-phenyl-ethanone: ${ }^{1} \mathbf{H}$ NMR $\left(400 \mathrm{MHz}, \mathrm{CDCl}_{3}\right) \delta$ 7.88-7.80 $(\mathrm{m}, 2 \mathrm{H}), 7.40-7.20(\mathrm{~m}, 7 \mathrm{H}), 5.90(\mathrm{~d}, J=6.0 \mathrm{~Hz}, 1 \mathrm{H}), 4.55(\mathrm{~d}, J=6.0 \mathrm{~Hz}, 1 \mathrm{H}) ;{ }^{13} \mathbf{C} \mathbf{N M R}(100$ $\left.\mathrm{MHz}, \mathrm{CDCl}_{3}\right) \delta 197.7,140.3,138.6,131.7,130.4,129.2,129.0,128.7,127.7,76.2$; TLC (3:1 hexanes/EtOAc) $\mathrm{R}_{f}$ 0.40; mp 97-100 ${ }^{\circ} \mathrm{C} ;[\alpha]_{\mathrm{D}}{ }^{25}+42(\mathrm{c}=1.0, \mathrm{EtOH})\left(\right.$ Lit.: $[\alpha]_{\mathrm{D}}{ }^{25}+10(\mathrm{c}=1.1$, $\mathrm{EtOH}, 22 \%$ ee) for $(S)$ configuration). ${ }^{10}$ 


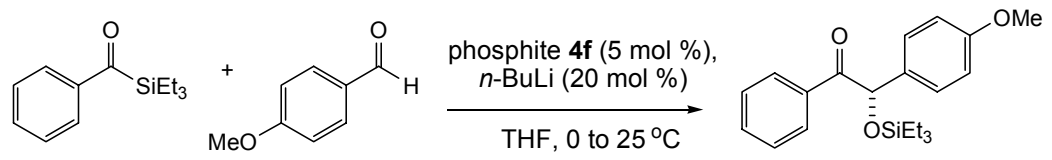

$\boldsymbol{S}$-(+)-1-phenyl-2-(4-methoxyphenyl)-2-triethylsilyloxy-ethanone $\quad(3 \mathrm{~d}) . \quad$ The title compound was prepared according to General Procedure B using $108 \mathrm{mg}(0.45 \mathrm{mmol})$ of acylsilane, $72 \mu \mathrm{L}(0.59 \mathrm{mmol})$ of $p$-anisaldehyde, $14 \mathrm{mg}(0.022 \mathrm{mmol})$ of phosphite $4 \mathbf{f}, 56 \mu \mathrm{L}$ $(0.088 \mathrm{mmol})$ of $n$-BuLi (1.6 M in hexanes), and $8 \mathrm{~mL}$ of THF. After $0.5 \mathrm{~h}$ from $0{ }^{\circ} \mathrm{C}$ to $25^{\circ} \mathrm{C}$, the crude product was purified by flash chromatography with 35:1 hexanes/EtOAc to afford $146 \mathrm{mg}$ $(91 \%)$ of the product as a clear oil in $91 \%$ ee as determined by CSP-SFC analysis $\left((S, S)\right.$-Whelk-O1, 1.0\% MeOH, $2.0 \mathrm{~mL} / \mathrm{min}, 200 \mathrm{psi}, 40{ }^{\circ} \mathrm{C}, 240 \mathrm{~nm}, t_{\mathrm{r}-\text { major }} 11.8 \mathrm{~min}, t_{\mathrm{r}-\operatorname{minor}} 10.3$ min). Spectral data matched that reported previously. ${ }^{5}[\alpha]_{\mathrm{D}}{ }^{25}+2.4\left(\mathrm{c}=0.35, \mathrm{CH}_{2} \mathrm{Cl}_{2}\right)$. CSP-SFC chromatograms for both racemic and $91 \%$ ee samples are shown below:
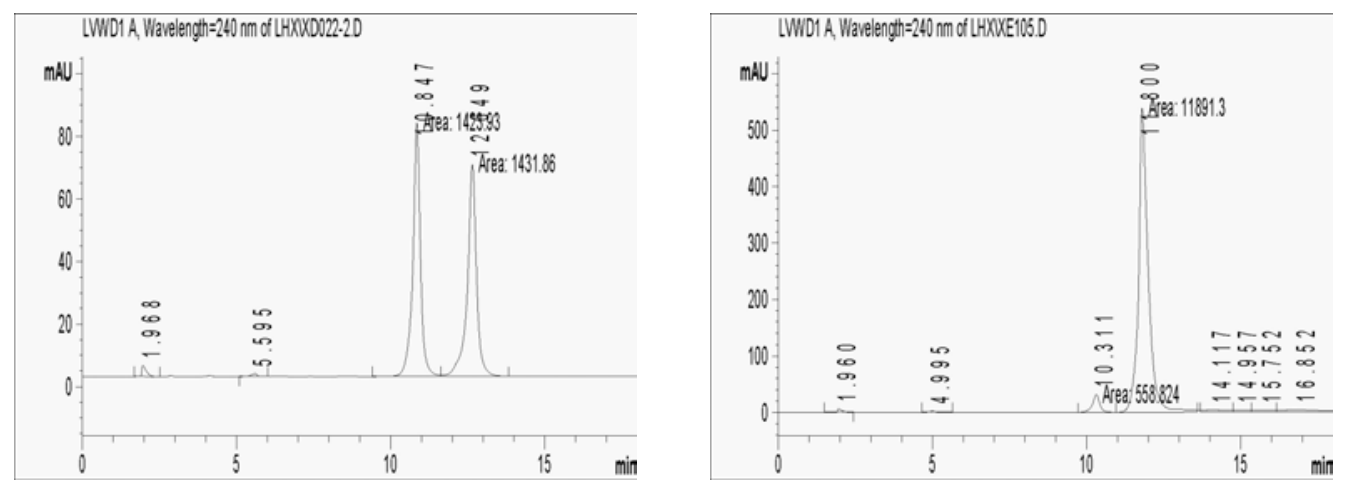

Deprotection of 3d. $10 \mathrm{~mL}$ of $\mathrm{MeOH}$ and $10 \mathrm{~mL} \mathrm{HCl}$ (3M aqueous solution) were added to a flask containing $83 \mathrm{mg}$ pure silyloxy ketone and the mixture was stirred for $10 \mathrm{~min}$ at $25^{\circ} \mathrm{C}$. The crude product was purified by flash chromatography with 7:3 hexanes/EtOAc to afford $48 \mathrm{mg}$ $(86 \%)$ of the corresponding hydroxy ketone product as white crystals. Analytical data for $S$-(+)-1-phenyl-2-(4-methoxyphenyl)-2-hydroxy-ethanone: ${ }^{\mathbf{1}} \mathbf{H} \quad \mathbf{N M R}\left(400 \mathrm{MHz}, \mathrm{CDCl}_{3}\right) \delta$ 7.90-7.87 (m, 2H) 7.51-7.47 (m, 1H) 7.38-7.36 (m, 2H) 7.24-7.22 (m, 2H) 6.83-6.81 (m, 2H) 5.90 $(\mathrm{d}, J=5.8 \mathrm{~Hz}, 1 \mathrm{H}) 4.49(\mathrm{~d}, J=6.0 \mathrm{~Hz}, 1 \mathrm{H}) 3.72(\mathrm{~s}, 3 \mathrm{H})$; TLC (7:3 hexanes/EtOAc) $\mathrm{R}_{f} 0.26 ; \mathrm{mp}$ $81-84{ }^{\circ} \mathrm{C} ;[\alpha]_{\mathrm{D}}{ }^{25}+111(\mathrm{c}=1.1$, acetone $)$.

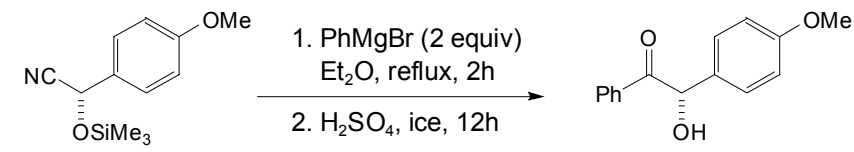

Determination of Absolute Configuration of 3d. To a stirred solution of 0.9 mmol phenyl magnesium bromide $\left(0.5 \mathrm{M}\right.$ in $\left.\mathrm{Et}_{2} \mathrm{O}\right)$ was added dropwise a solution of $100 \mathrm{mg}(0.43 \mathrm{mmol})$ silylcyanohydrin ${ }^{11}$ in $1 \mathrm{~mL} \mathrm{Et}_{2} \mathrm{O}$ under Ar. The reaction mixture was heated under reflux for $2 \mathrm{~h}$ and then poured into a mixture of ice $(2 \mathrm{~g})$ and conc. $\mathrm{H}_{2} \mathrm{SO}_{4}(0.075 \mathrm{ml})$ and stirred for $12 \mathrm{~h}$. The crude product was extracted with $\mathrm{Et}_{2} \mathrm{O}(3 \times 10 \mathrm{~mL})$, dried $\left(\mathrm{MgSO}_{4}\right)$ and purified by flash chromatography with 7:3 hexanes/EtOAc to afford $73 \mathrm{mg}(71 \%)$ of the product as a pale yellow oil. Analytical data for $S$-(+)-1-phenyl-2-(4-methoxyphenyl)-2-hydroxy-ethanone: ${ }^{1} \mathbf{H}$ NMR $\left(400 \mathrm{MHz}, \mathrm{CDCl}_{3}\right) \delta$ 7.92-7.89 (m, 2H) 7.52-7.49 (m, 1H) 7.41-7.39 (m, 2H) 7.26-7.24 (m, 2H) 
6.86-6.83 (m, 2H) $5.91(\mathrm{~d}, J=5.8 \mathrm{~Hz}, 1 \mathrm{H}) 4.47(\mathrm{~d}, J=6.0 \mathrm{~Hz}, 1 \mathrm{H}), 3.76(\mathrm{~s}, 3 \mathrm{H})$; TLC (7:3 hexanes/EtOAc) $\mathrm{R}_{f} 0.25 ;[\alpha]_{\mathrm{D}}{ }^{25}+100(\mathrm{c}=1.1$, acetone $)$.

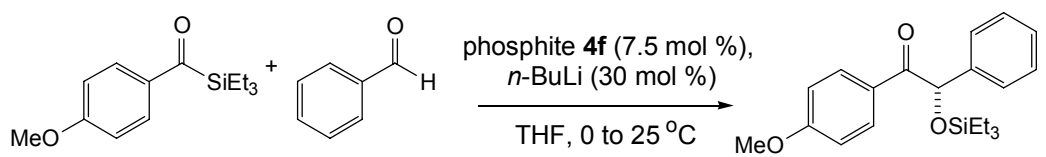

$S$-(-)-1-(4-methoxyphenyl)-2-phenyl-2-triethylsilyloxy-ethanone (3e). The title compound was prepared according to General Procedure B using $80 \mathrm{mg}(0.32 \mathrm{mmol})$ of acylsilane, $39 \mu \mathrm{L}(0.38 \mathrm{mmol})$ of benzaldehyde, $19 \mathrm{mg}(0.032 \mathrm{mmol})$ of phosphite $4 \mathbf{f}, 60 \mu \mathrm{L}(0.096 \mathrm{mmol})$ of $n$-BuLi (1.6 M in hexanes), and $6 \mathrm{~mL}$ of THF. After $0.5 \mathrm{~h}$ from $0{ }^{\circ} \mathrm{C}$ to $25^{\circ} \mathrm{C}$, the crude product was purified by flash chromatography with $20: 1$ hexanes/EtOAc to afford $94 \mathrm{mg}(83 \%)$ of the product as a clear oil in $88 \%$ ee as determined by CSP-SFC analysis ( $(S, S)$-Whelk-O1, $1.0 \%$ $\left.\mathrm{MeOH}, 2.0 \mathrm{~mL} / \mathrm{min}, 200 \mathrm{psi}, 40{ }^{\circ} \mathrm{C}, 240 \mathrm{~nm}, t_{\mathrm{r} \text {-major }} 11.2 \mathrm{~min}, t_{\mathrm{r}-\text { minor }} 10.2 \mathrm{~min}\right)$. Spectral data matched that reported previously. ${ }^{5}[\alpha]_{\mathrm{D}}{ }^{25}-41\left(\mathrm{c}=1.95, \mathrm{CH}_{2} \mathrm{Cl}_{2}\right)$. CSP-SFC chromatograms for both racemic and $88 \%$ ee samples are shown below:
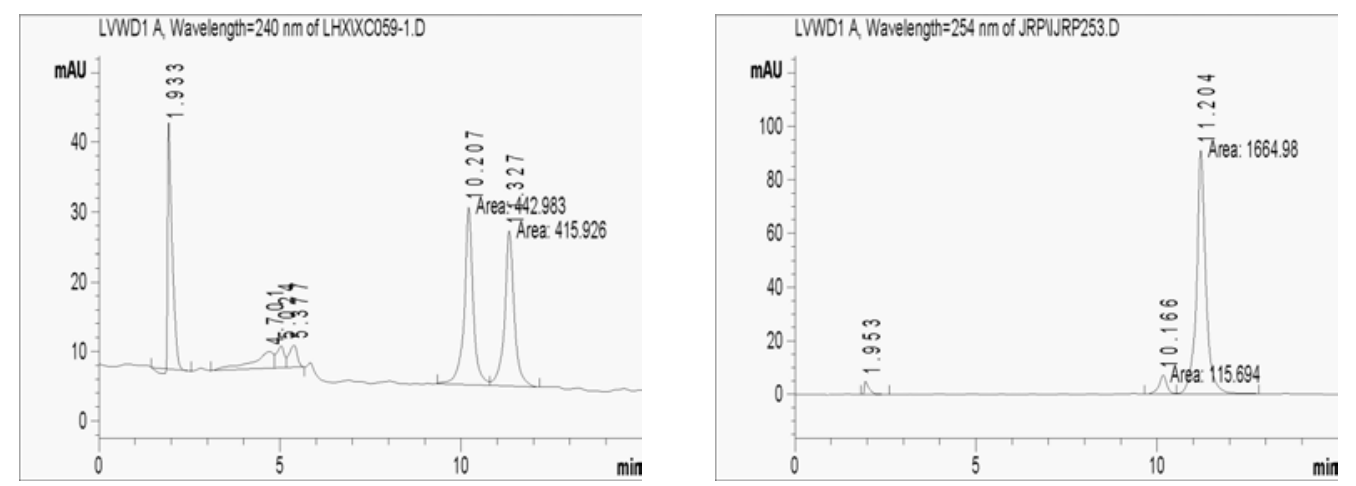

Deprotection of 3e. $10 \mathrm{~mL}$ of $\mathrm{MeOH}$ and $10 \mathrm{~mL} \mathrm{HCl}$ (1M aqueous solution) were added to a flask containing $72 \mathrm{mg}$ pure silyloxy ketone and the mixture was stirred for $10 \mathrm{~min}$ at $25^{\circ} \mathrm{C}$. The crude product was purified by flash chromatography with 2:1 hexanes/EtOAc to afford $47 \mathrm{mg}$ (95\%) of the corresponding hydroxy ketone product as white crystals. Analytical data for $S$-(+)-1-(4-methoxyphenyl)-2-hydroxy-2-phenyl-ethanone: ${ }^{1} \mathbf{H}$ NMR $\left(400 \mathrm{MHz}, \mathrm{CDCl}_{3}\right) \delta 7.91$ (d, $J=8.4 \mathrm{~Hz}, 2 \mathrm{H}), 7.40-7.20(\mathrm{~m}, 5 \mathrm{H}), 6.86(\mathrm{~d}, J=8.4 \mathrm{~Hz}, 2 \mathrm{H}), 5.89(\mathrm{~d}, J=6.0 \mathrm{~Hz}, 1 \mathrm{H}), 4.63(\mathrm{~d}, J=$ $6.0 \mathrm{~Hz}, 1 \mathrm{H}), 3.82(\mathrm{~s}, 3 \mathrm{H})$; TLC $\left(2: 1\right.$ hexanes/EtOAc) $\mathrm{R}_{f} 0.3 ; \mathrm{mp} 100-102{ }^{\circ} \mathrm{C} ;[\alpha]_{\mathrm{D}}{ }^{25}+57(\mathrm{c}=1.1$, EtOH $)\left(\right.$ Lit.: $[\alpha]_{\mathrm{D}}{ }^{25}+19(\mathrm{c}=0.66$, EtOH, $24 \%$ ee $)$ for $(S)$ configuration $) .{ }^{10}$

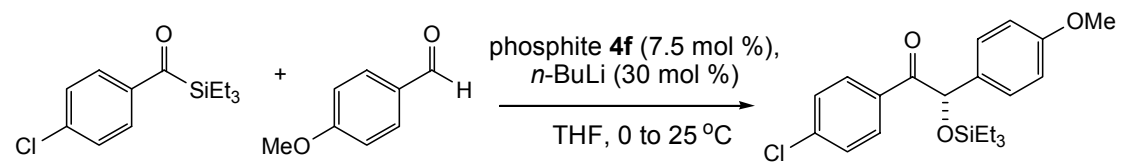

$S$-(-)-1-(4-chlorophenyl)-2-(4-methoxyphenyl)-2-triethylsilyloxy-ethanone (3f). The title compound was prepared according to General Procedure B using $119 \mathrm{mg}(0.47 \mathrm{mmol})$ of acylsilane, $86 \mu \mathrm{L}(0.70 \mathrm{mmol})$ of $p$-anisaldehyde, $21 \mathrm{mg}(0.035 \mathrm{mmol})$ of phosphite $4 \mathbf{f}, 90 \mu \mathrm{L}$ $(0.14 \mathrm{mmol})$ of $n$-BuLi (1.6 M in hexanes), and $8 \mathrm{~mL}$ of THF. After $0.5 \mathrm{~h}$ from $0{ }^{\circ} \mathrm{C}$ to $25^{\circ} \mathrm{C}$, the crude product was purified by flash chromatography with 35:1 hexanes/EtOAc to afford $153 \mathrm{mg}$ (84\%) of the product as a clear oil in $90 \%$ ee as determined by CSP-SFC analysis 
((S,S)-Whelk-O1, 1.0\% MeOH, $2.0 \mathrm{~mL} / \mathrm{min}, 200 \mathrm{psi}, 40{ }^{\circ} \mathrm{C}, 240 \mathrm{~nm}, t_{\mathrm{r}-\text { major }} 9.7 \mathrm{~min}, t_{\mathrm{r}-\text { minor }} 8.2$ min). Spectral data matched that reported previously. ${ }^{5}[\alpha]_{\mathrm{D}}{ }^{25}-11\left(\mathrm{c}=0.55, \mathrm{CH}_{2} \mathrm{Cl}_{2}\right) . \mathrm{CSP}-\mathrm{SFC}$ chromatograms for both racemic and $90 \%$ ee samples are shown below:
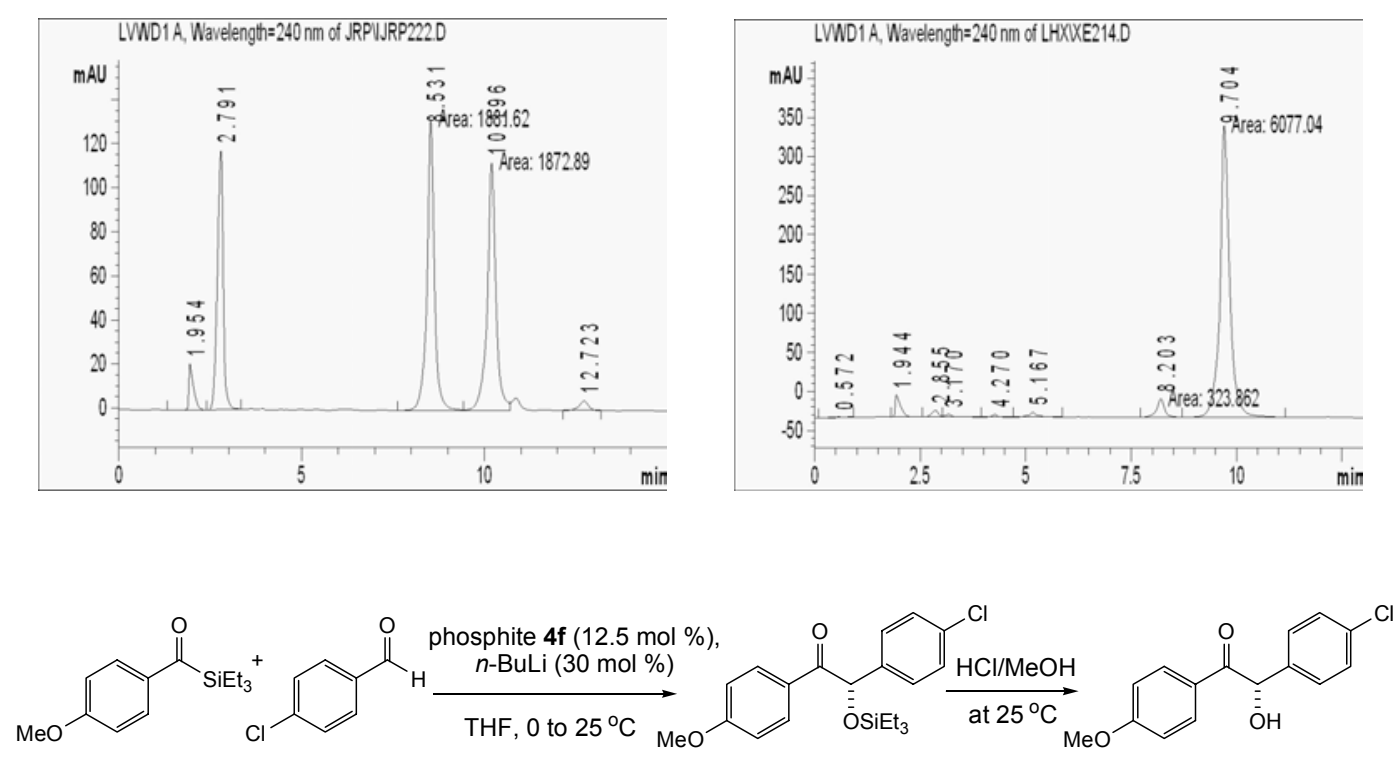

S-(+)-1-(4-methoxyphenyl)-2-(4-chlorophenyl)-2-hydroxy-ethanone (3g). The title compound was prepared according to General Procedure B using $120 \mathrm{mg}(0.48 \mathrm{mmol})$ of acylsilane, $101 \mathrm{mg}(0.72 \mathrm{mmol})$ of $p$-chlorobenzaldehyde, $35 \mathrm{mg}(0.06 \mathrm{mmol})$ of phosphite $\mathbf{4 f}, 90$ $\mu \mathrm{L}(0.14 \mathrm{mmol})$ of $n$-BuLi $\left(1.6 \mathrm{M}\right.$ in hexanes), and $8 \mathrm{~mL}$ of THF. After $0.5 \mathrm{~h}$ from $0{ }^{\circ} \mathrm{C}$ to $25^{\circ} \mathrm{C}$, the solvent was removed with a rotary evaporator. $15 \mathrm{~mL}$ of $\mathrm{MeOH}$ and $15 \mathrm{~mL} \mathrm{HCl}(1 \mathrm{M}$ aqueous solution) were added and the mixture was stirred for $10 \mathrm{~min}$ at $25^{\circ} \mathrm{C}$ before $15 \mathrm{~mL} \mathrm{Et}_{2} \mathrm{O}$ was added to the flask. The organic layer was separated and the aqueous layer was extracted with two $15 \mathrm{~mL}$ portions of $\mathrm{Et}_{2} \mathrm{O}$. The organic extracts were combined, dried $\left(\mathrm{MgSO}_{4}\right)$, and the solvent was removed with a rotary evaporator. The crude product was purified by flash chromatography with 2:1 hexanes/EtOAc to afford $105 \mathrm{mg}(79 \%, 2$ steps) of the product as a waxy solid in $83 \%$ ee as determined by CSP-SFC analysis ( $(S, S)$-Whelk-O1, $2.0 \% \mathrm{MeOH}, 2.0 \mathrm{~mL} / \mathrm{min}, 200 \mathrm{psi}, 40{ }^{\circ} \mathrm{C}, 240$ $\left.\mathrm{nm}, \quad t_{\mathrm{r}-\text { major }} \quad 12.8 \mathrm{~min}, \quad t_{\mathrm{r}-\text { minor }} 23.3 \mathrm{~min}\right)$. Analytical data for S-(+)-1-(4-methoxyphenyl)-2-(4-chlorophenyl)-2-hydroxy-ethanone: IR (thin film, $\mathrm{cm}^{-1}$ ) 3750-3100 (br), 3070, 3010, 2966, 2935, 2841, 1668, 1599, 1574, 1500, 1490, 1463, 1410, 1311, $1261,1174,1082,1028,975,910,856,827,735,615 ;{ }^{1} \mathbf{H} \mathbf{N M R}\left(400 \mathrm{MHz}, \mathrm{CDCl}_{3}\right) \delta 7.85(\mathrm{~d}, J=$ $8.8 \mathrm{~Hz}, 2 \mathrm{H}), 7.24(\mathrm{~s}, 4 \mathrm{H}), 6.84(\mathrm{~d}, J=8.8 \mathrm{~Hz}, 2 \mathrm{H}), 5.85(\mathrm{~s}, 1 \mathrm{H}), 4.80-4.40$ (broad, 1H), 3.78 (s, $3 \mathrm{H}) ;{ }^{13} \mathbf{C}$ NMR $\left(100 \mathrm{MHz}, \mathrm{CDCl}_{3}\right) \delta 196.7,164.1,138.0,134.2,131.4,129.1,129.0,125.9113 .9$, 74.8, 55.4; TLC (3:1 hexanes/EtOAc) $\mathrm{R}_{f}$ 0.17; For ${ }^{1} \mathrm{H}$ NMR spectrum, see Appendix; $[\alpha]_{\mathrm{D}}{ }^{25}+33$ $\left(\mathrm{c}=0.53, \mathrm{CH}_{2} \mathrm{Cl}_{2}\right.$ ). CSP-SFC chromatograms for both racemic and $83 \%$ ee samples are shown below: 

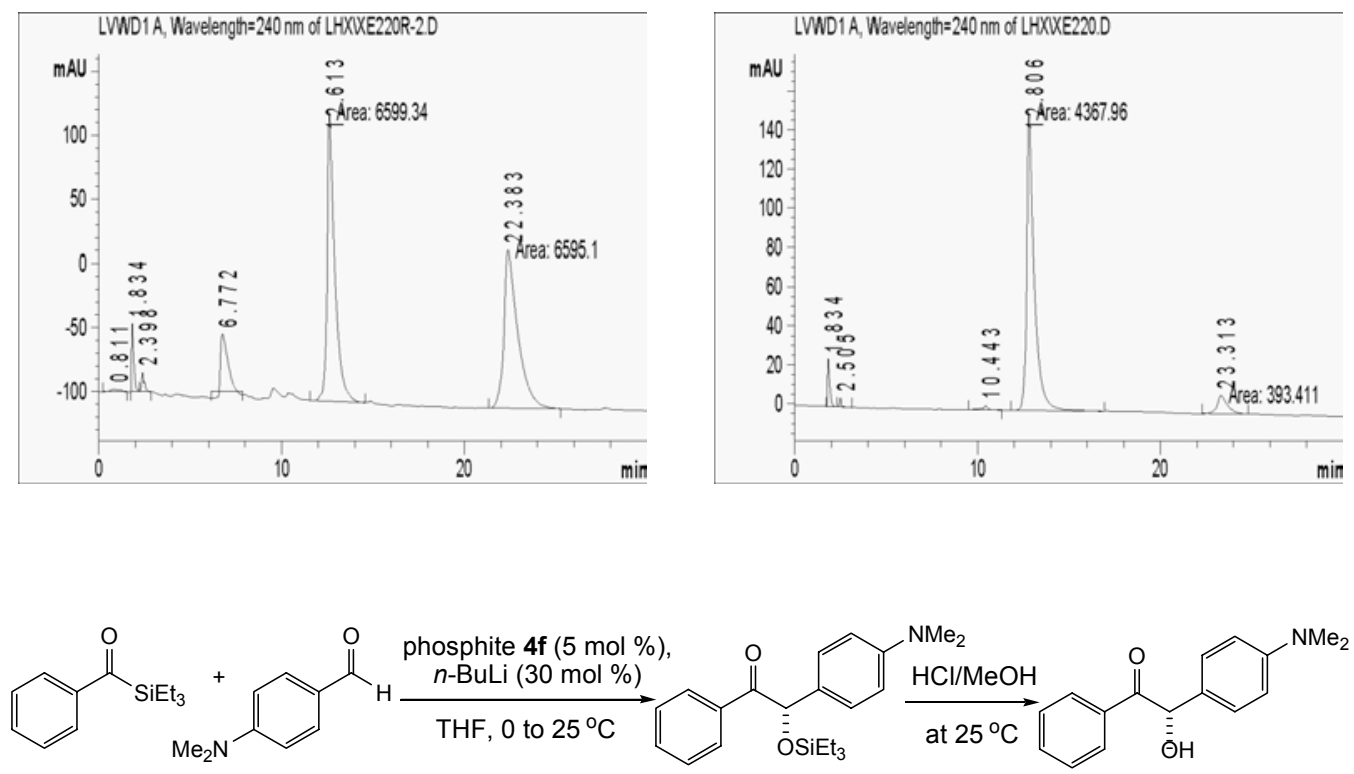

$S$-(+)-1-phenyl-2-(4-dimethylaminophenyl)-2-hydroxy-ethanone $\quad(3 \mathbf{h}) . \quad$ The title compound was prepared according to General Procedure B using $150 \mathrm{mg}(0.68 \mathrm{mmol})$ of acylsilane, $152 \mathrm{mg}(1.02 \mathrm{mmol})$ of $p$-dimethylaminobenzaldehyde, $20 \mathrm{mg}(0.034 \mathrm{mmol})$ of phosphite $4 \mathbf{f}, 130 \mu \mathrm{L}(0.20 \mathrm{mmol})$ of $n$-BuLi (1.6 M in hexanes), and $10 \mathrm{~mL}$ of THF. After $0.5 \mathrm{~h}$ from $0{ }^{\circ} \mathrm{C}$ to $25{ }^{\circ} \mathrm{C}$, the solvent was removed with a rotary evaporator. $10 \mathrm{~mL}$ of $\mathrm{MeOH}$ and 10 $\mathrm{mL} \mathrm{HCl}\left(1 \mathrm{M}\right.$ aqueous solution) were added and the mixture was stirred for $10 \mathrm{~min}$ at $25{ }^{\circ} \mathrm{C}$. Saturated aqueous $\mathrm{NaHCO}_{3}$ was added until $\mathrm{pH}>10$, and $15 \mathrm{~mL} \mathrm{Et}_{2} \mathrm{O}$ was added to the flask. The organic layer was separated and the aqueous layer was extracted with two $15 \mathrm{~mL}$ portions of $\mathrm{Et}_{2} \mathrm{O}$. The organic extracts were combined, dried $\left(\mathrm{MgSO}_{4}\right)$, and the solvent was removed with a rotary evaporator. The crude product was purified by flash chromatography with 2:1 hexanes/EtOAc to afford $135 \mathrm{mg}$ (79\%, 2 steps) of the product as a waxy solid in $84 \%$ ee as determined by CSP-SFC analysis (Chiralpak AS, 2.0\% MeOH, $2.0 \mathrm{~mL} / \mathrm{min}, 200 \mathrm{psi}, 40{ }^{\circ} \mathrm{C}, 240 \mathrm{~nm}, t_{\mathrm{r} \text {-major }} 27.1 \mathrm{~min}, t_{\mathrm{r} \text {-minor }}$ $31.2 \mathrm{~min}$ ). Analytical data for $S$-(+)-1-phenyl-2-(4-dimethylaminophenyl)-2-hydroxy-ethanone: IR (Nujol mull, $\mathrm{cm}^{-1}$ ) 3413, 2918, 2856, 1678, 1616, 1525, 1460, 1377, 1263, 1167, 1084, 974, 812, 727; ${ }^{1} \mathbf{H}$ NMR $\left(300 \mathrm{MHz}, \mathrm{CDCl}_{3}\right) \delta 7.93(\mathrm{~d}, J=7.5 \mathrm{~Hz}, 2 \mathrm{H}), 7.50(\mathrm{dt}, J=7.5 \mathrm{~Hz}, J=2.1 \mathrm{~Hz}, 1 \mathrm{H})$, $7.38(\mathrm{t}, J=7.5 \mathrm{~Hz}, 2 \mathrm{H}), 7.17(\mathrm{dt}, J=8.7 \mathrm{~Hz}, J=2.1 \mathrm{~Hz}, 2 \mathrm{H}), 6.65(\mathrm{~d}, J=8.4 \mathrm{~Hz}, 2 \mathrm{H}), 5.88(\mathrm{~d}, J=$ $6.0 \mathrm{~Hz}, 1 \mathrm{H}), 4.41(\mathrm{~d}, J=6.0 \mathrm{~Hz}, 1 \mathrm{H}), 2.90(\mathrm{~s}, 6 \mathrm{H}) ;{ }^{13} \mathbf{C} \mathbf{~ N M R}\left(100 \mathrm{MHz}, \mathrm{CDCl}_{3}\right) \delta 199.2,150.5$, 133.8, 133.5, 129.1, 128.7, 128.6, 126.5, 112.7, 75.9, 40.3; TLC (3:1 hexanes/EtOAc) $\mathrm{R}_{f}$ 0.24; For ${ }^{1} \mathrm{H}$ NMR spectrum, see Appendix; mp $148-152{ }^{\circ} \mathrm{C} ;[\alpha]_{\mathrm{D}}{ }^{25}+187\left(\mathrm{c}=0.75, \mathrm{CH}_{2} \mathrm{Cl}_{2}\right)$. CSP-SFC chromatograms for both racemic and $84 \%$ ee samples are shown below: 

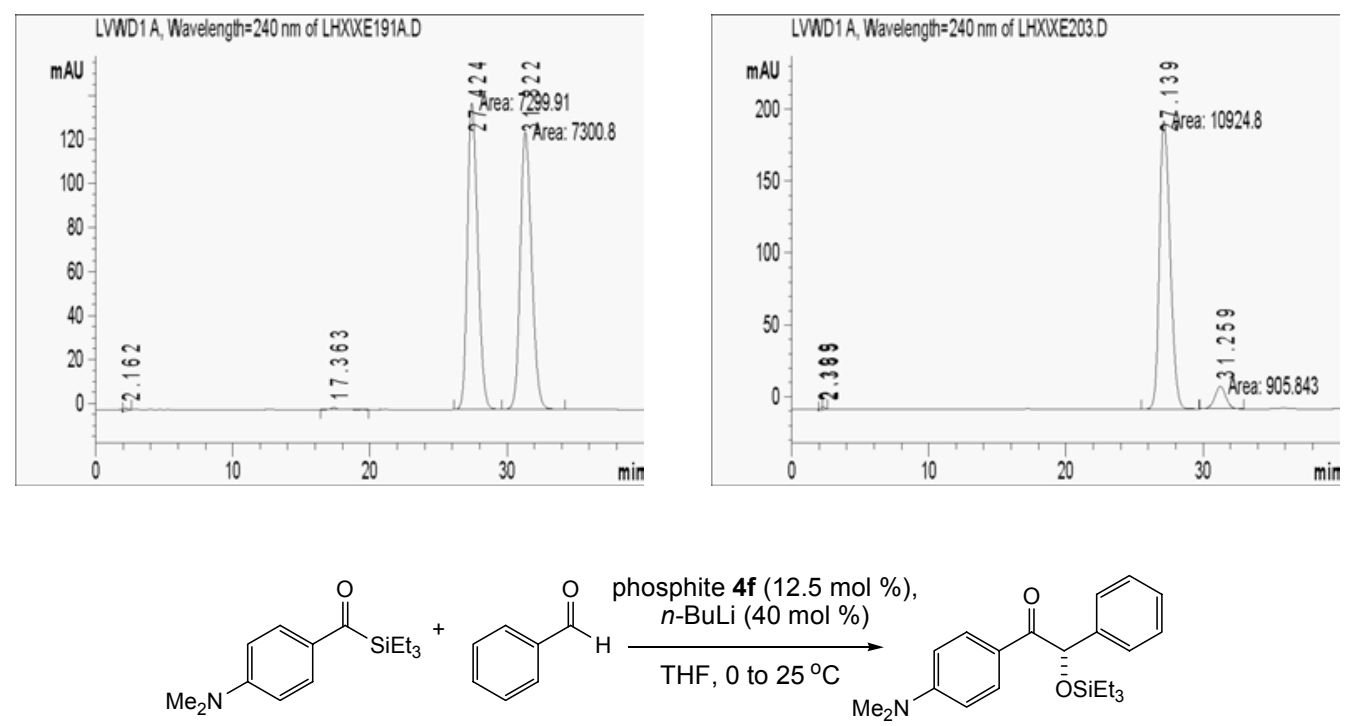

S-(-)-1-(4-dimethylaminophenyl)-2-phenyl-2-triethylsilyloxy-ethanone (3i). The title compound was prepared according to General Procedure B using $114 \mathrm{mg}(0.44 \mathrm{mmol})$ of acylsilane, $66 \mu \mathrm{L}(0.65 \mathrm{mmol})$ of benzaldehyde, $38 \mathrm{mg}(0.066 \mathrm{mmol})$ of phosphite $4 \mathbf{f}, 100 \mu \mathrm{L}$ $(0.16 \mathrm{mmol})$ of $n$-BuLi (1.6 M in hexanes), and $8 \mathrm{~mL}$ of THF. After $0.5 \mathrm{~h}$ from $0{ }^{\circ} \mathrm{C}$ to $25^{\circ} \mathrm{C}$, the crude product was purified by flash chromatography with 16:1 hexanes/EtOAc to afford $139 \mathrm{mg}$ (86\%) of the product as a clear oil in $86 \%$ ee as determined by CSP-SFC analysis (Chiralcel OD-H, $1.5 \% \mathrm{MeOH}, 2.0 \mathrm{~mL} / \mathrm{min}, 200 \mathrm{psi}, 40{ }^{\circ} \mathrm{C}, 240 \mathrm{~nm}, t_{\mathrm{r}-\text { major }} 23.4 \mathrm{~min}, t_{\mathrm{r}-\text { minor }} 26.3 \mathrm{~min}$ ). Spectral data matched that reported previously. ${ }^{5}[\alpha]_{\mathrm{D}}{ }^{25}-40\left(\mathrm{c}=1.2, \mathrm{CH}_{2} \mathrm{Cl}_{2}\right)$. CSP-SFC chromatograms for both racemic and $86 \%$ ee samples are shown below:
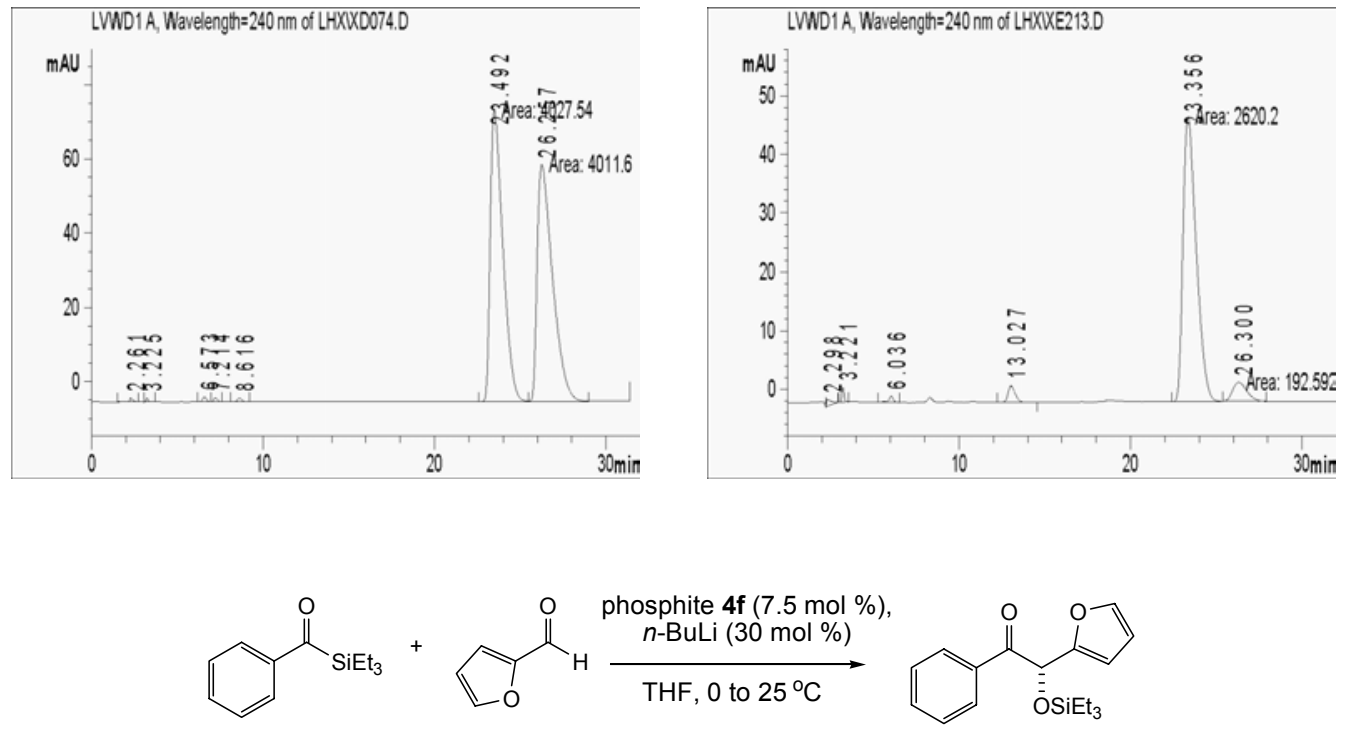

S-(+)-1-phenyl-2-(2-furyl)-2-triethylsilyloxy-ethanone (3j). The title compound was prepared according to General Procedure B using $110 \mathrm{mg}(0.50 \mathrm{mmol})$ of acylsilane, $62 \mu \mathrm{L}(0.75$ mmol) of 2-furaldehyde, $22 \mathrm{mg}(0.037 \mathrm{mmol})$ of phosphite $4 \mathbf{f}, 94 \mu \mathrm{L}(0.15 \mathrm{mmol})$ of $n$-BuLi (1.6 $\mathrm{M}$ in hexanes), and $8 \mathrm{~mL}$ of THF. After $0.5 \mathrm{~h}$ from $0{ }^{\circ} \mathrm{C}$ to $25^{\circ} \mathrm{C}$, the crude product was purified by flash chromatography with 35:1 hexanes/EtOAc to afford $105 \mathrm{mg}(66 \%)$ of the product as a 
clear oil. Spectral data matched that reported previously. ${ }^{5}[\alpha]_{\mathrm{D}}{ }^{25}+49\left(\mathrm{c}=0.46, \mathrm{CH}_{2} \mathrm{Cl}_{2}\right)$.

Deprotection of 3j. $10 \mathrm{~mL}$ of $\mathrm{MeOH}$ and $10 \mathrm{~mL} \mathrm{HCl}$ (1M aqueous solution) were added to a flask containing $82 \mathrm{mg}$ of $\mathbf{3 j}$ and the mixture was stirred for $10 \mathrm{~min}$ at $25^{\circ} \mathrm{C}$. After workup, the crude product was purified by flash chromatography with 3:1 hexanes/EtOAc to afford $46 \mathrm{mg}$ (87\%) of the corresponding hydroxy ketone product as white crystals in $88 \%$ ee as determined by CSP-SFC analysis (Chiralpak AS, 2.0\% MeOH, $2.0 \mathrm{~mL} / \mathrm{min}, 200 \mathrm{psi}, 40{ }^{\circ} \mathrm{C}, 240 \mathrm{~nm}, t_{\mathrm{r}-\mathrm{major}} 6.4$ $\left.\min , t_{\mathrm{r}-\mathrm{minor}} 7.4 \mathrm{~min}\right)$. Analytical data for $S$-(+)-1-phenyl-2-(2-furyl)-2-hydroxy-ethanone: IR (Nujol mull, $\mathrm{cm}^{-1}$ ) 3423, 3377, 2951, 2910, 2850, 1678, 1597, 1578, 1462, 1377, 1300, 1230, 1217 , 1151, 1068, 1016, 972, 915, 845, 746, 684, 669; ${ }^{1} \mathbf{H}$ NMR (400 MHz, $\left.\mathrm{CDCl}_{3}\right) \delta 7.95$ (d, $J=8.0$ $\mathrm{Hz}, 2 \mathrm{H}), 7.57$ (t, $J=7.6 \mathrm{~Hz}, 1 \mathrm{H}), 7.43$ (t, $J=8.0 \mathrm{~Hz}, 2 \mathrm{H}), 7.34$ (s, 1H), 6.33 (dt, $J=7.6 \mathrm{~Hz}, J=$ $3.2 \mathrm{~Hz}, 2 \mathrm{H}), 6.02(\mathrm{~d}, J=6.4 \mathrm{~Hz}, 1 \mathrm{H}), 4.41(\mathrm{~d}, J=6.4 \mathrm{~Hz}, 1 \mathrm{H}) ;{ }^{13} \mathbf{C ~ N M R}\left(100 \mathrm{MHz}, \mathrm{CDCl}_{3}\right) \delta$ 195.9, 151.6, 143.1, 134.1, 133.2, 128.9, 128.7, 110.8, 109.1, 69.3; TLC (5:1 hexanes/EtOAc) $\mathrm{R}_{f}$ 0.18; mp 130-133 ${ }^{\circ} \mathrm{C}$; For ${ }^{1} \mathrm{H}$ NMR spectra, see Appendix; $[\alpha]_{\mathrm{D}}{ }^{25}+90\left(\mathrm{c}=0.81, \mathrm{CH}_{2} \mathrm{Cl}_{2}\right)$. CSP-SFC chromatograms for both racemic and $88 \%$ ee samples are shown below:
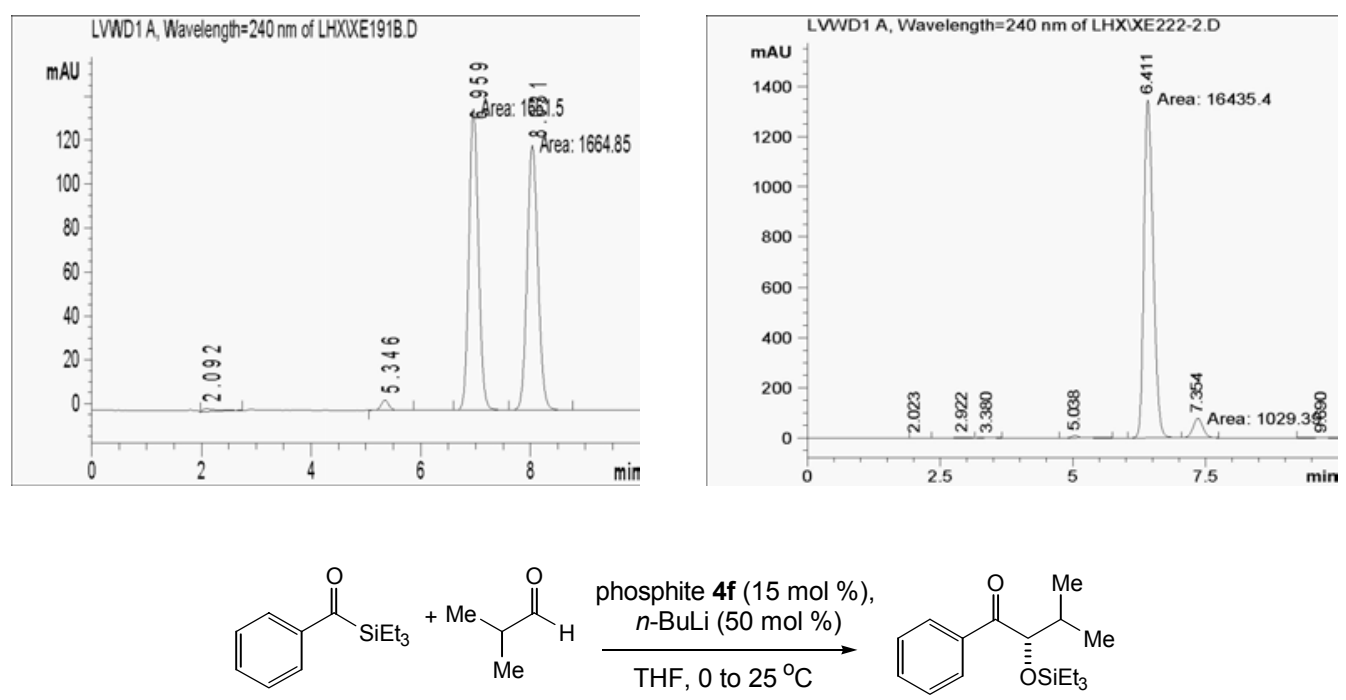

$S$-(-)-1-phenyl-2-triethylsilyloxy-3-methyl-butanone (3k). The title compound was prepared according to General Procedure B using $100 \mathrm{mg}(0.45 \mathrm{mmol})$ of acylsilane, $65 \mu \mathrm{L}(0.73$ mmol) of isobutyraldehyde, $40 \mathrm{mg}(0.068 \mathrm{mmol})$ of phosphite $4 \mathbf{f}, 140 \mu \mathrm{L}(0.23 \mathrm{mmol})$ of $n$-BuLi (1.6 M in hexanes), and $8 \mathrm{~mL}$ of THF. After $0.5 \mathrm{~h}$ from $0{ }^{\circ} \mathrm{C}$ to $25^{\circ} \mathrm{C}$, the crude product was purified by flash chromatography with $45: 1$ hexanes/EtOAc to afford $105 \mathrm{mg}$ (79\%) of the product as a clear oil in $73 \%$ ee as determined by CSP-SFC analysis $((S, S)$-Whelk-O1, $0.5 \%$ $\left.\mathrm{MeOH}, 1.5 \mathrm{~mL} / \mathrm{min}, 150 \mathrm{psi}, 40{ }^{\circ} \mathrm{C}, 254 \mathrm{~nm}, t_{\mathrm{r}-\text { major }} 5.5 \mathrm{~min}, t_{\mathrm{r}-\text { minor }} 6.5 \mathrm{~min}\right)$. Spectral data matched that reported previously. ${ }^{5}[\alpha]_{\mathrm{D}}{ }^{25}-27\left(\mathrm{c}=0.35, \mathrm{CH}_{2} \mathrm{Cl}_{2}\right)$. CSP-SFC chromatograms for both racemic and $73 \%$ ee samples are shown below: 

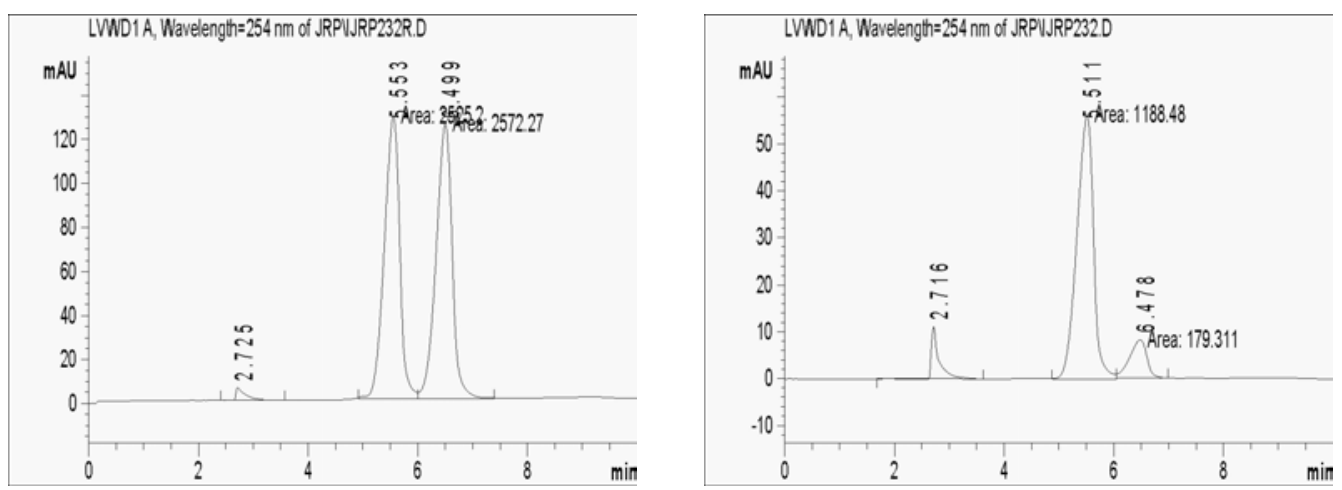

Deprotection of 3k. $10 \mathrm{~mL}$ of $\mathrm{MeOH}$ and $10 \mathrm{~mL} \mathrm{HCl}$ (3M aqueous solution) were added to a flask containing $130 \mathrm{mg}$ pure silyloxy ketone and the mixture was stirred for $1 \mathrm{~h}$ at $25^{\circ} \mathrm{C}$. The crude product was purified by flash chromatography with 4:1 hexanes/EtOAc to afford $28 \mathrm{mg}$ (35\%) of the corresponding hydroxy ketone product as a clear oil. Analytical data for $S$-(+)-1-phenyl-2-hydroxy-3-methylbutanone: ${ }^{1} \mathbf{H}$ NMR $\left(400 \mathrm{MHz}, \mathrm{CDCl}_{3}\right) \delta$ 7.91-7.88 (m, 2H) 7.62-7.60 (m, 1H) 7.52-7.48 (m, 2H) $4.98(\mathrm{dd}, J=6.4 \mathrm{~Hz}, J=2.4 \mathrm{~Hz}, 1 \mathrm{H}), 3.60(\mathrm{~d}, J=6.4 \mathrm{~Hz}, 1 \mathrm{H})$ 2.13 (dsept, $J=6.9 \mathrm{~Hz}, J=2.5 \mathrm{~Hz}, 1 \mathrm{H}) 1.17(\mathrm{~d}, J=6.9 \mathrm{~Hz}, 3 \mathrm{H}) 0.65$ (d, $J=6.8 \mathrm{~Hz}, 3 \mathrm{H})$; TLC (4:1 hexanes/EtOAc) $\mathrm{R}_{f} 0.36$; $[\alpha]_{\mathrm{D}}{ }^{25}+13\left(\mathrm{c}=1.4\right.$, EtOH) $\left(\mathrm{Lit} .:[\alpha]_{546}{ }^{25}+20(\mathrm{c}=2.2\right.$, EtOH, $100 \%$ ee for $(S)$ configuration). ${ }^{12}$

As a second check of absolute configuration, $S$-(+)-1-phenyl-2-hydroxy-3-methylbutanone was independently prepared by addition of $\mathrm{PhMgBr}$ to (S)-3-methyl-2trimethylsilyloxybutanenitrile and subsequent hydrolysis. The (silyloxy)nitrile starting material $\left(64 \%\right.$ ee) was synthesized by Belokon's method. ${ }^{11}$ Observed optical rotation for $S$-(+)-1-phenyl-2-hydroxy-3-methylbutanone prepared in this way: $[\alpha]_{\mathrm{D}}{ }^{25}+12(\mathrm{c}=1.1, \mathrm{EtOH})$.

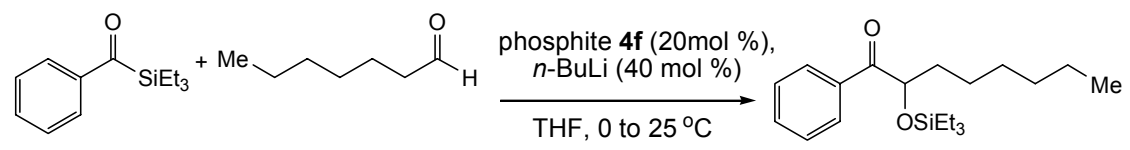

(-)-1-phenyl-2-triethylsilyloxy-octanone (31). The title compound was prepared according to General Procedure B using $124 \mathrm{mg}(0.56 \mathrm{mmol})$ of acylsilane, $120 \mu \mathrm{L}(0.84 \mathrm{mmol})$ of heptanal, $66 \mathrm{mg}(0.11 \mathrm{mmol})$ of phosphite $4 \mathbf{f}, 140 \mu \mathrm{L}(0.23 \mathrm{mmol})$ of $n-\mathrm{BuLi}(1.6 \mathrm{M}$ in hexanes), and $9 \mathrm{~mL}$ of THF. After $0.5 \mathrm{~h}$ from $0{ }^{\circ} \mathrm{C}$ to $25{ }^{\circ} \mathrm{C}$, the crude product was purified by flash chromatography with $50: 1$ hexanes/EtOAc to afford $158 \mathrm{mg}(84 \%)$ of the product as a clear oil in $41 \%$ ee as determined by CSP-SFC analysis $((S, S)$-Whelk-O1, $0.5 \% \mathrm{MeOH}, 1.5 \mathrm{~mL} / \mathrm{min}$, $\left.150 \mathrm{psi}, 40{ }^{\circ} \mathrm{C}, 254 \mathrm{~nm}, t_{\mathrm{r}-\mathrm{major}} 8.2 \mathrm{~min}, t_{\mathrm{r}-\operatorname{minor}} 9.8 \mathrm{~min}\right)$. Spectral data matched that reported previously. ${ }^{5}[\alpha]_{\mathrm{D}}{ }^{25}-13\left(\mathrm{c}=0.93, \mathrm{CH}_{2} \mathrm{Cl}_{2}\right)$. CSP-SFC chromatograms for both racemic and $41 \%$ ee samples are shown below: 

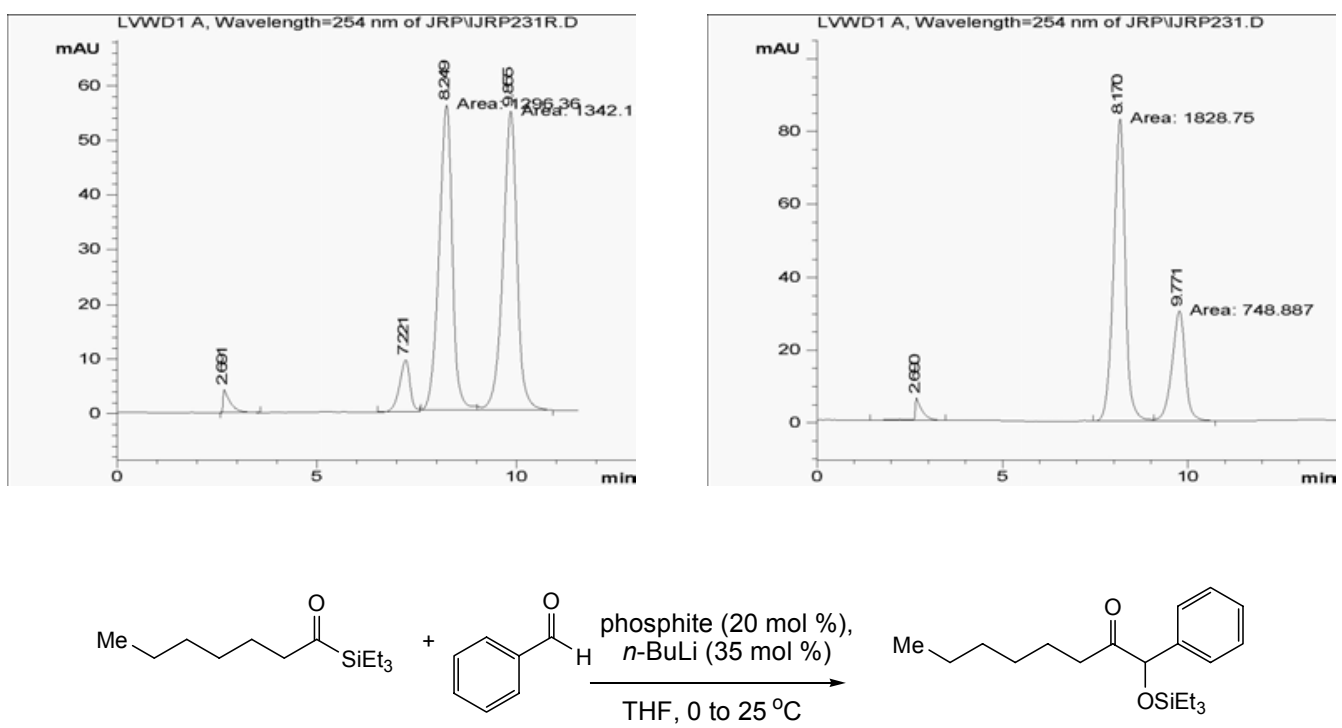

(-)-(1-triethylsilyloxy)-benzyl-hexyl-ketone (3m). The title compound was prepared according to General Procedure B using $100 \mathrm{mg}(0.44 \mathrm{mmol})$ of acylsilane, $67 \mu \mathrm{L}(0.66 \mathrm{mmol})$ of benzaldehyde, $51 \mathrm{mg}(0.088 \mathrm{mmol})$ of phosphite $4 \mathbf{f}, 82 \mu \mathrm{L}(0.13 \mathrm{mmol})$ of $n$-BuLi $(1.6 \mathrm{M}$ in hexanes), and $8 \mathrm{~mL}$ of THF. After $0.5 \mathrm{~h}$ from $0{ }^{\circ} \mathrm{C}$ to $25{ }^{\circ} \mathrm{C}$, the crude product was purified by flash chromatography with $4: 1$ petroleum ether/ $\mathrm{CH}_{2} \mathrm{Cl}_{2}$ to afford $108 \mathrm{mg}(74 \%)$ of the product as a clear oil in $67 \%$ ee as determined by CSP-SFC analysis $((S, S)$-Whelk-O1, $0.5 \% \mathrm{MeOH}, 1.5$ $\left.\mathrm{mL} / \mathrm{min}, 150 \mathrm{psi}, 40{ }^{\circ} \mathrm{C}, 254 \mathrm{~nm}, t_{\mathrm{r}-\text { major }} 13.1 \mathrm{~min}, t_{\mathrm{r}-\text { minor }} 7.0 \mathrm{~min}\right)$. Spectral data matched that reported previously. ${ }^{5}[\alpha]_{\mathrm{D}}{ }^{25}-10\left(\mathrm{c}=1.2, \mathrm{CH}_{2} \mathrm{Cl}_{2}\right)$. CSP-SFC chromatograms for both racemic and $67 \%$ ee samples are shown below:
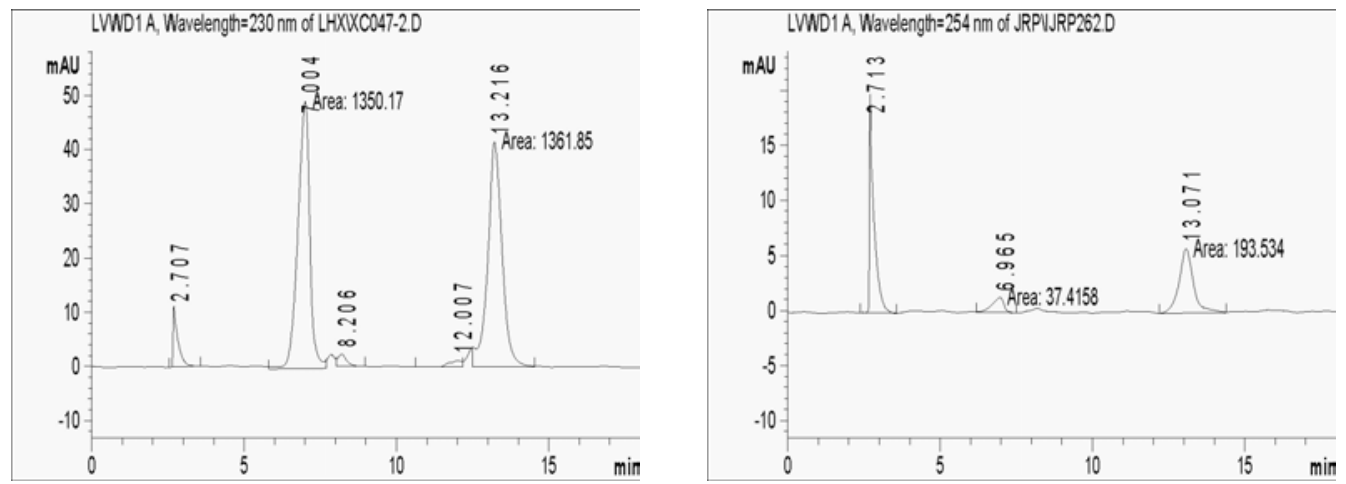


\section{References}

(1) Alaimo, P. J.; Peters, D. W.; Arnold, J.; Bergman, R. G. J. Chem. Ed. 2001, 78, 64.

(2) Linghu, X.; Nicewicz, D. A.; Johnson, J. S. Org. Lett. 2002, 4, 2957-2960.

(3) Seebach, D.; Beck, A. K.; Heckel, A. Angew. Chem. Int. Ed. 2001, 40, 92-138.

(4) Hafner, A.; Duthaler, R. O.; Marti, R.; Rihs, G.; Rothe-Streit, P.; Schwarzenbach, F. J. Am. Chem. Soc. 1992, 114, 2321-36.

(5) Linghu, X.; Johnson, J. S. Angew. Chem. Int. Ed. 2003, 42, 2534-2536.

(6) Greene, N.; Kee, T. P. Synth. Commun. 1993, 23, 1651-7.

(7) Enders, D.; Tedeschi, L.; Bats, J. W. Angew. Chem. Int. Ed. 2000, 39, 4605-4607.

(8) Berens, U.; Leckel, D.; Oepen, S. C. J. Org. Chem. 1995, 60, 8204-8.

(9) Li, W.; Waldkirch, J. P.; Zhang, X. J. Org. Chem. 2002, 67, 7618-7623.

(10) Imuta, M.; Ziffer, H. J. Org. Chem. 1978, 43, 3319-23.

(11) Belokon, Y. N.; Caveda-Cepas, S.; Green, B.; Ikonnikov, N. S.; Khrustalev, V. N.; Larichev, V. S.; Moscalenko, M. A.; North, M.; Orizu, C.; Tararov, V. I.; Tasinazzo, M.; Timofeeva, G. I.; Yashkina, L. V. J. Am. Chem. Soc. 1999, 121, 3968-3973.

(12) Maigrot, N.; Mazaleyrat, J. P.; Welvart, Z. J. Org. Chem. 1985, 50, 3916-18. 


\section{Appendix :}

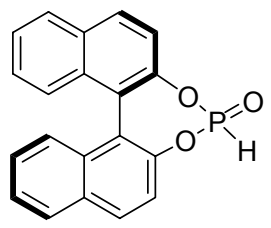

4b

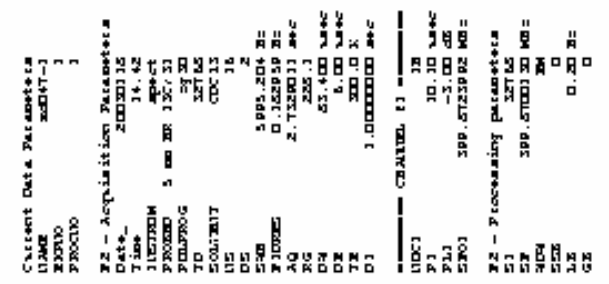

$170^{\circ} z$

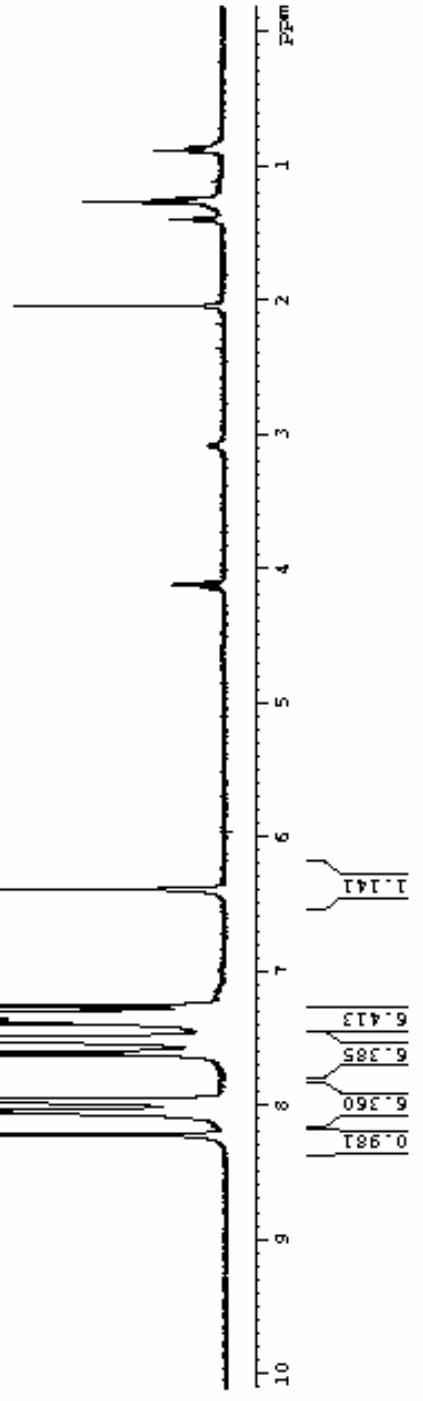




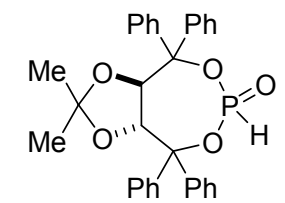

$4 c$
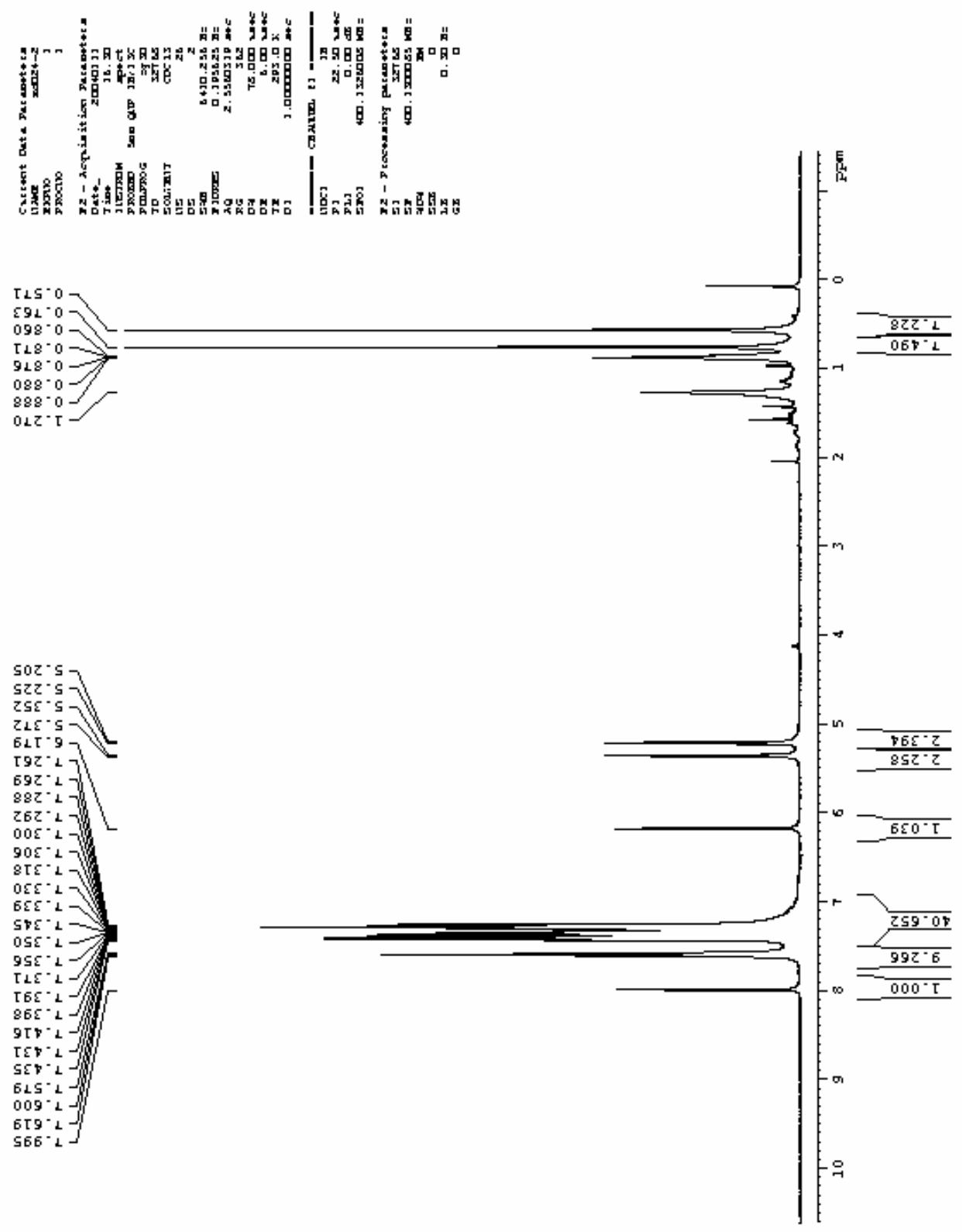


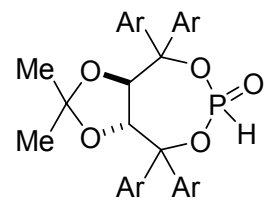

$$
\mathrm{Ar}=2-\mathrm{MePh}
$$

$4 d$
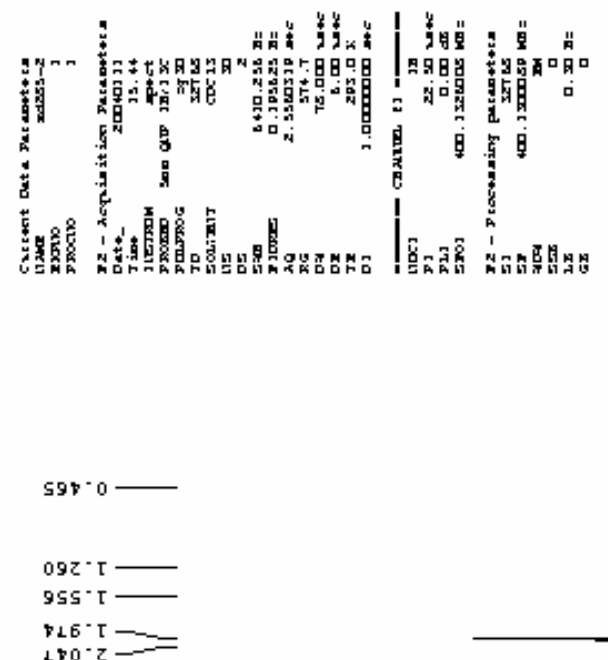

路

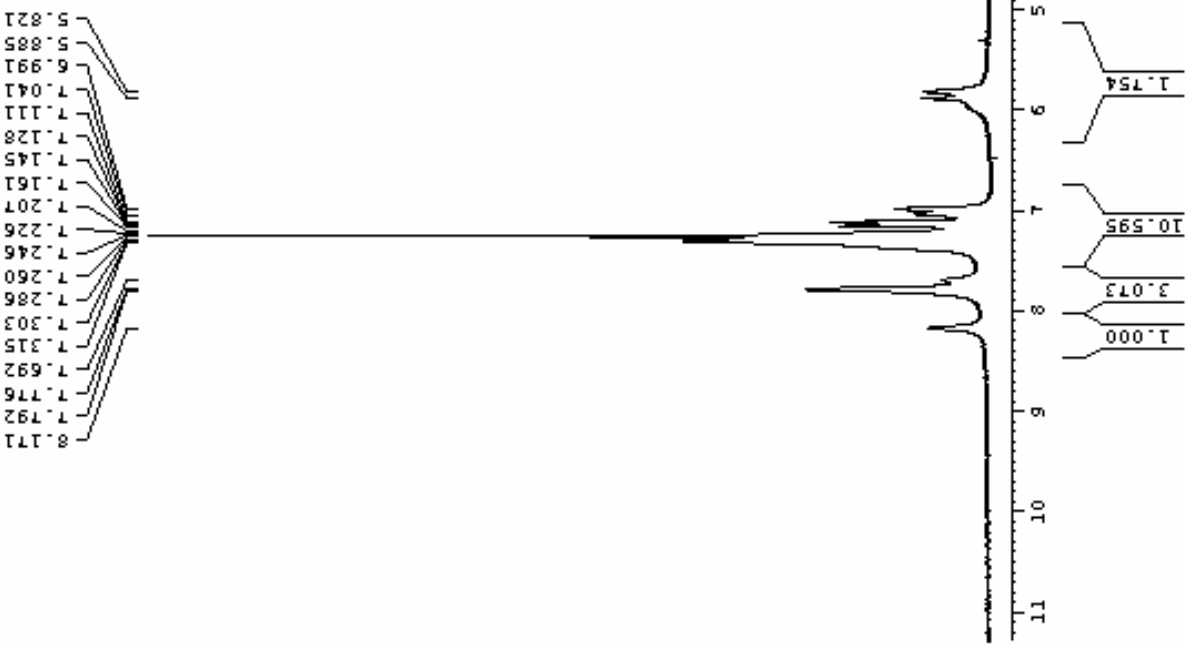




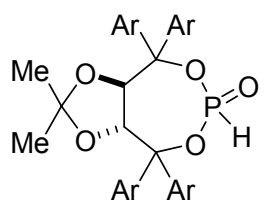

$\mathrm{Ar}=$ 2-naphthyl

$4 e$
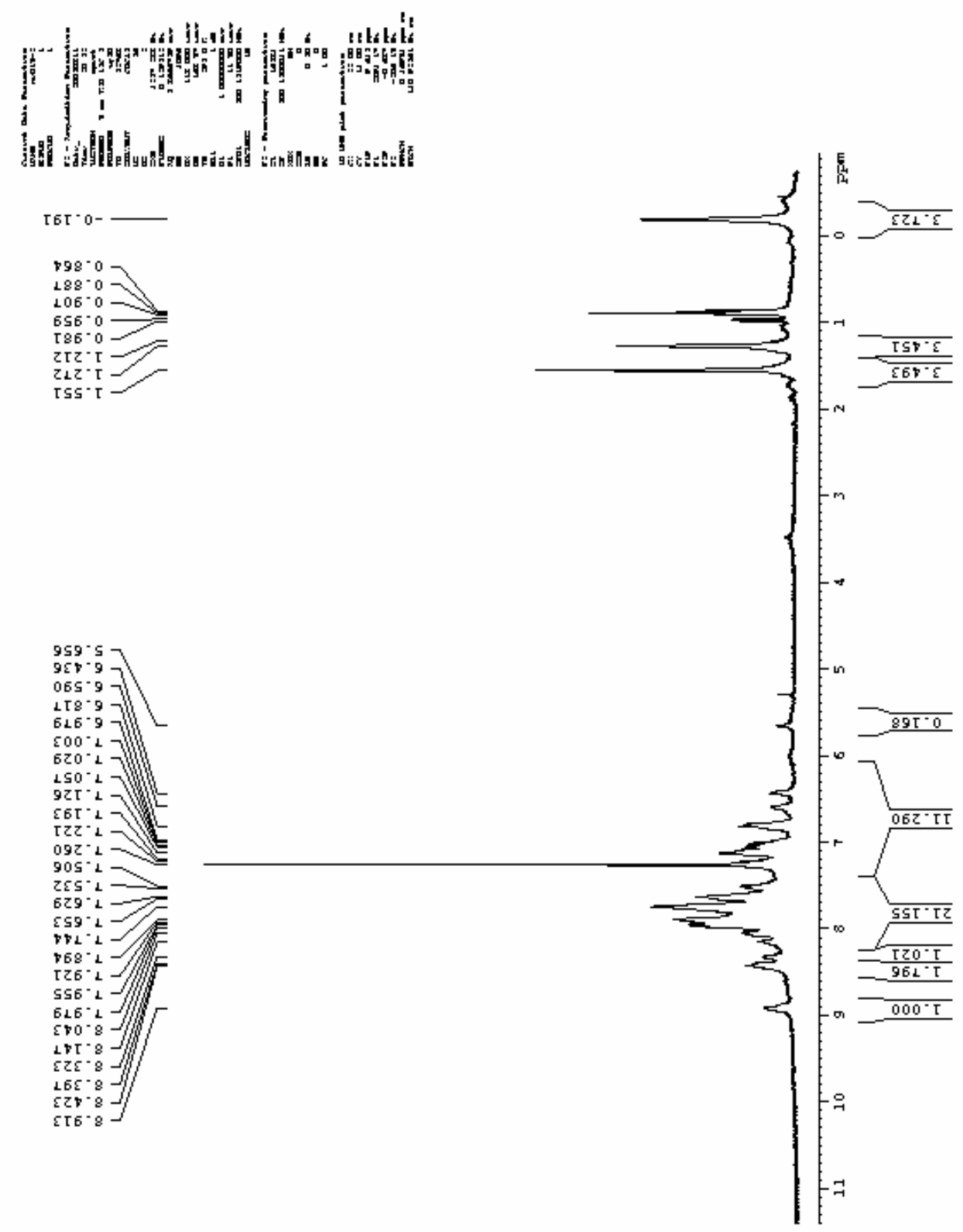


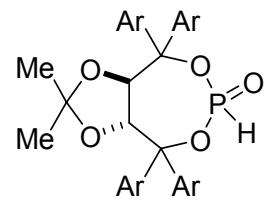

$\mathrm{Ar}=2-\mathrm{FPh}$

$4 f$

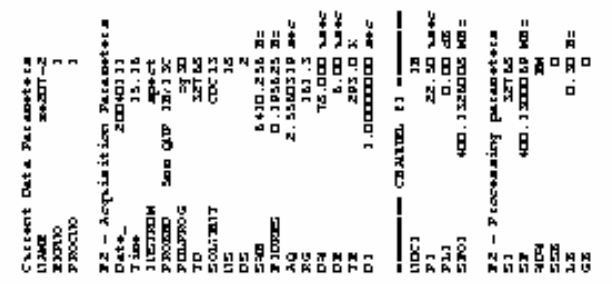

oTs

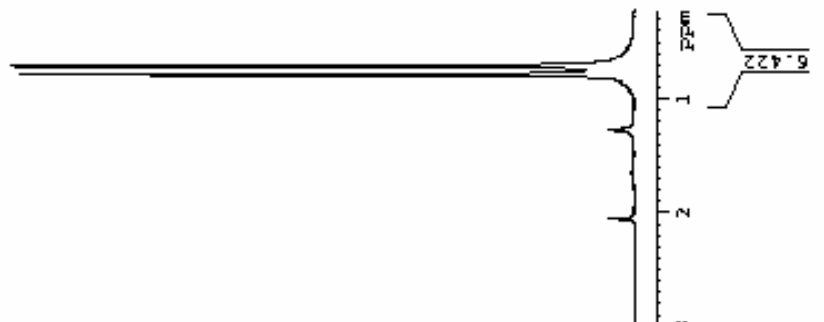

$\operatorname{pos} 57$
$\operatorname{tos} 57$

EEs-57

टर $2-57$

8se- 57

5TE-

TE- 9

cse-g

$>0^{-} \perp-1$

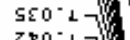

270-1

$120-1-$

$50[-1$

I

ELC-

$\cos 2$

095

TEL $\perp T^{-} \perp$

top $1-$

ezt- 1

gzg- $1-$

659-2

$0 \div \perp-M$

951- $1-$

$1 L \perp-1-$

ITE-1-

$150^{-} 2-$

$\operatorname{sic} 2]$

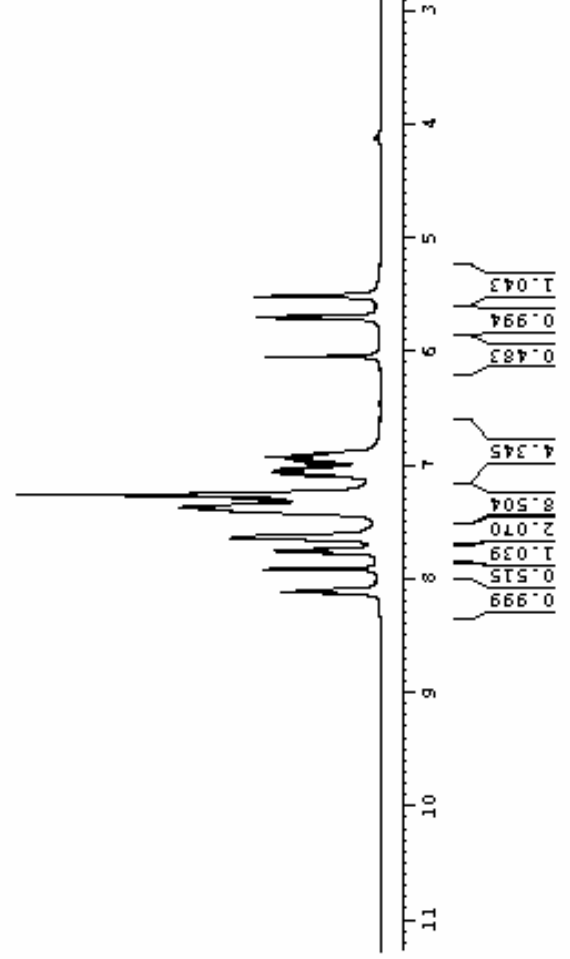




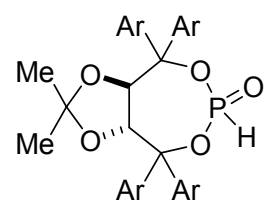

$\mathrm{Ar}=2,6-\mathrm{F}_{2} \mathrm{Ph}$

$4 g$

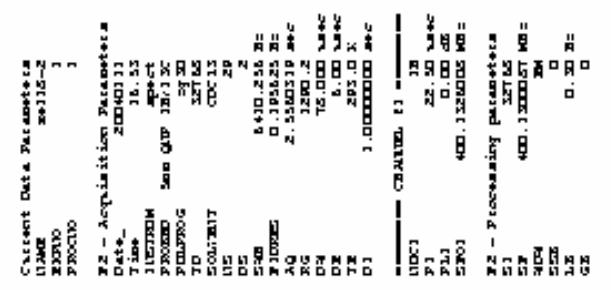

ระL.

$\operatorname{cst}[-$

E.5. 0.7

$9 \operatorname{son}$
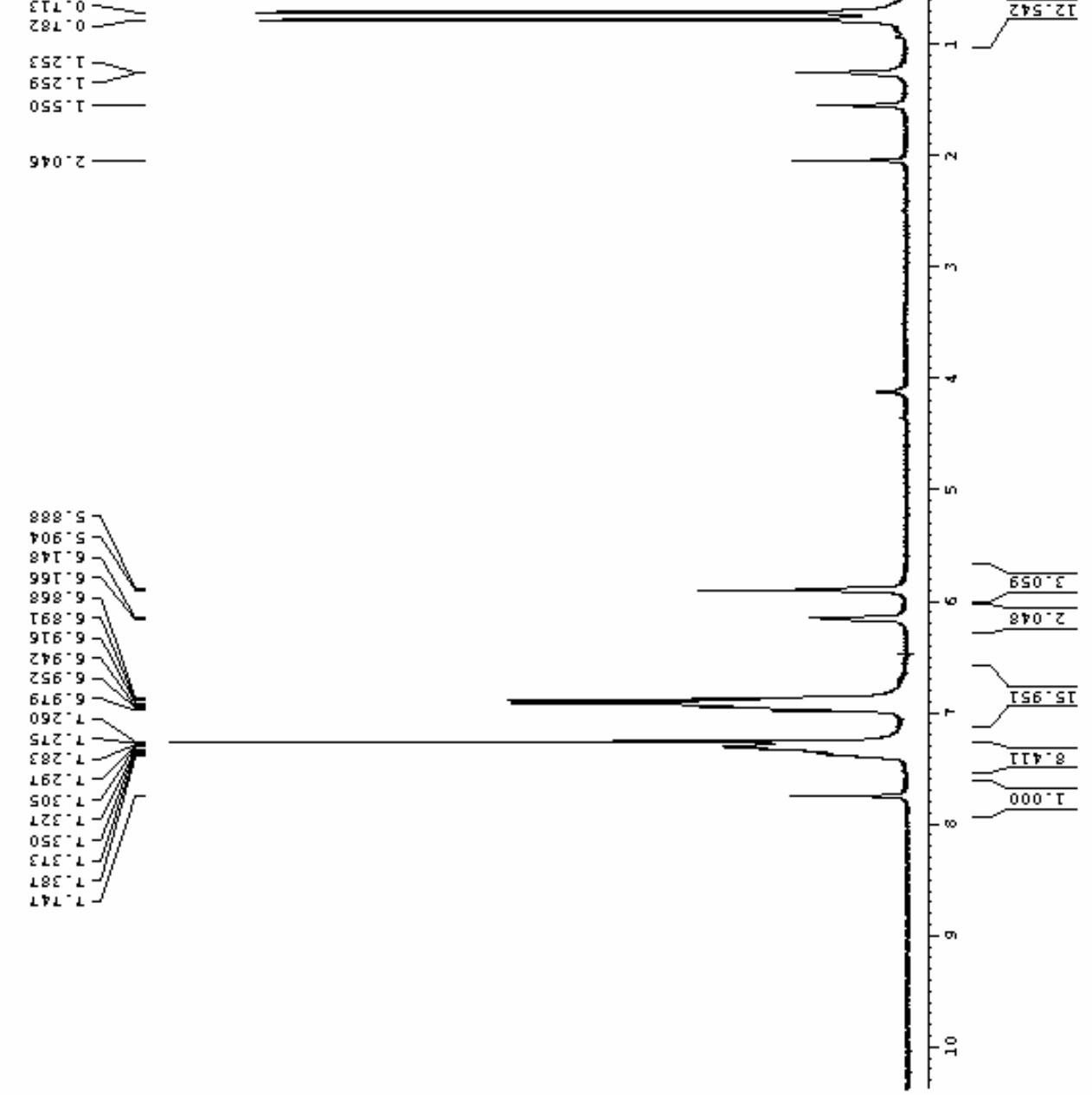


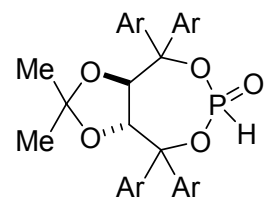

$\mathrm{Ar}=\mathrm{F}_{5} \mathrm{Ph}$

4h

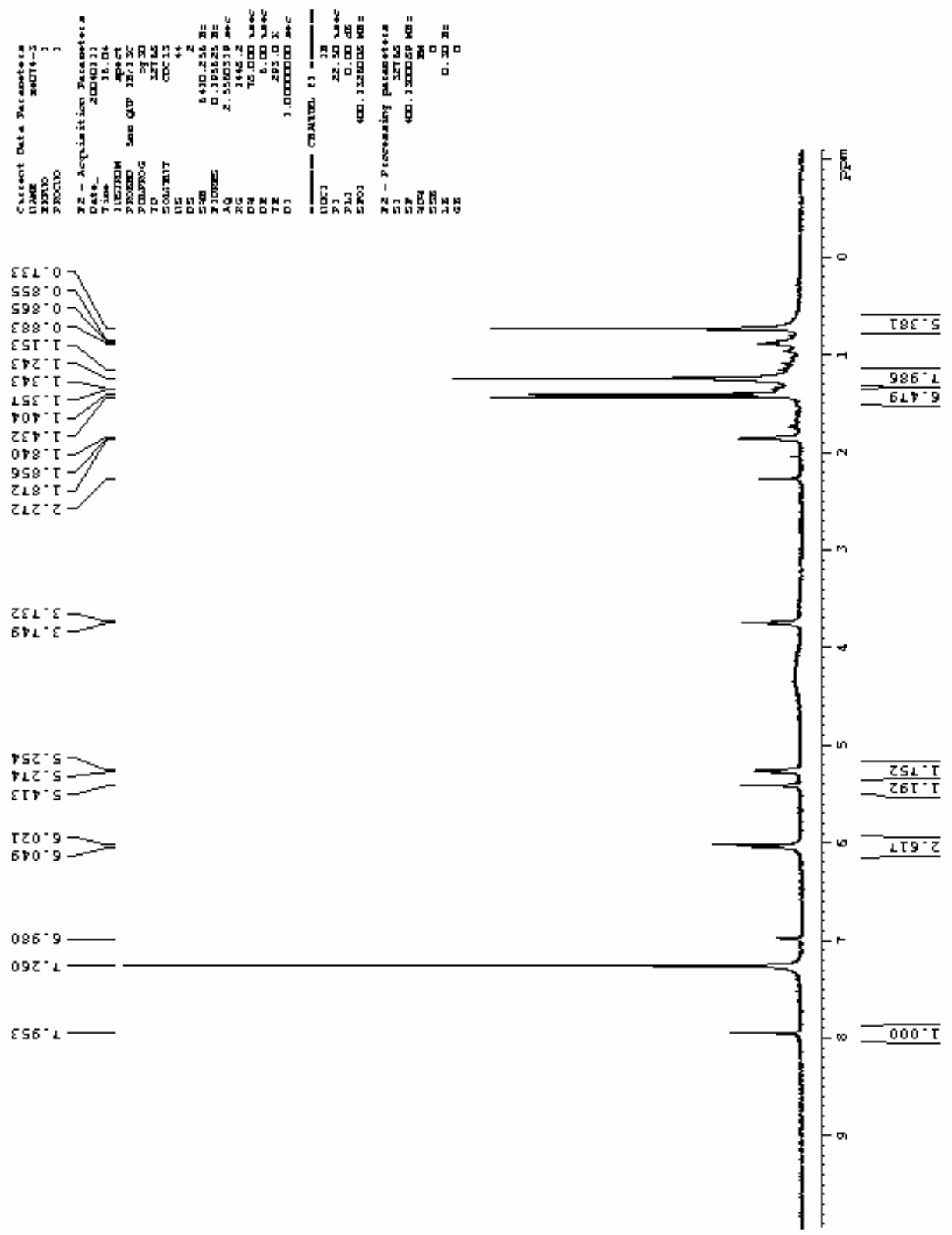




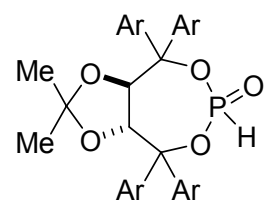

$\mathrm{Ar}=2-\mathrm{CF}_{3} \mathrm{Ph}$

$4 i$

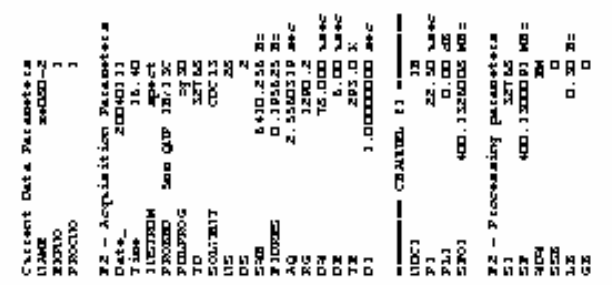

E.000

ssz:c

Tgz:

$555^{\circ}$
$905=$

$170^{\circ} z$
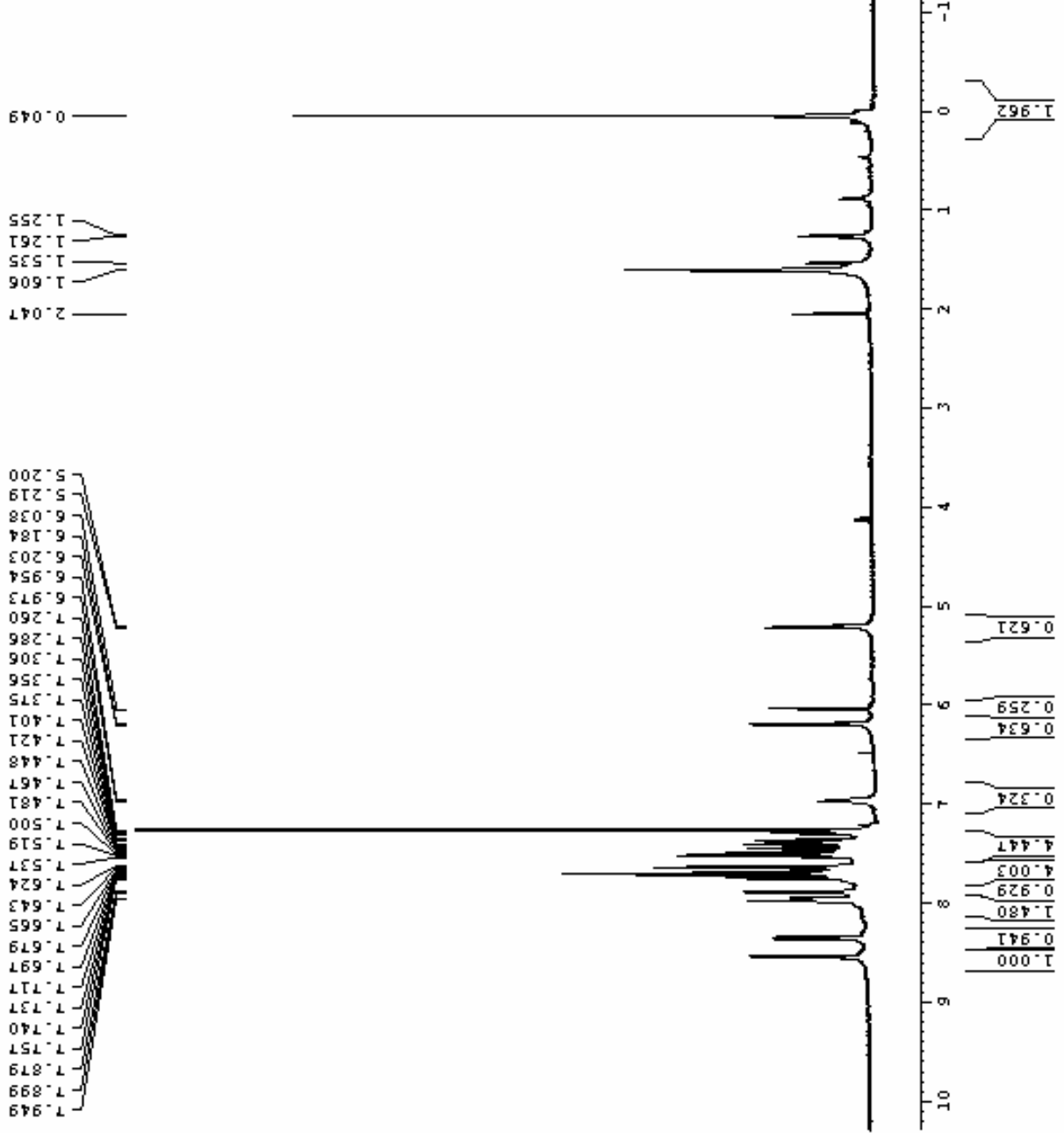


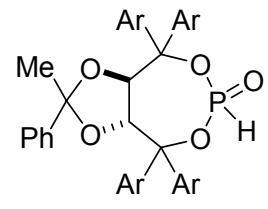

$\mathrm{Ar}=2-\mathrm{FPh}$

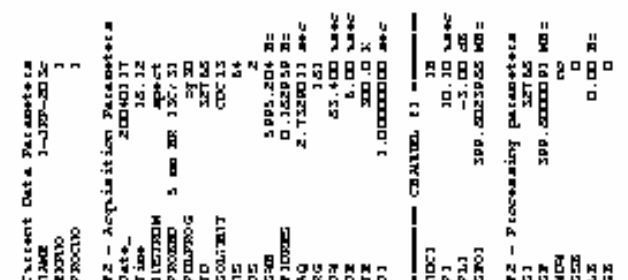

EEC: 5

$002 \cdot 5$

$505 \cdot 5$

otg.s]

ors. $\mathrm{s}$

EEL 5

I20.5-

258.5

200.5

867. 9

Ecs.

हns.

655.9

EQ5.

2Es

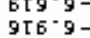

हटE- 9

ORE-g-

195.9

$19 E-9$

TLE 9

ह8E-9-

$880^{\circ} \mathrm{g}$

SEE-9

9EE-9

$020^{\circ}-1$

$520^{\circ} \perp$

$520^{\circ} \perp 7$

9po-1

E90.-

$8 \angle 0^{\circ} \perp$

$580^{\circ} \perp$

$\$ 60^{\circ} \perp$

Zot: 1

pot 1

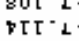

TET: 2

Op[-2]

ET T-

$155^{\circ} \perp$

$\tau \perp \mathrm{T} \perp-$

Iㄴㄷㄴㄷㄴ

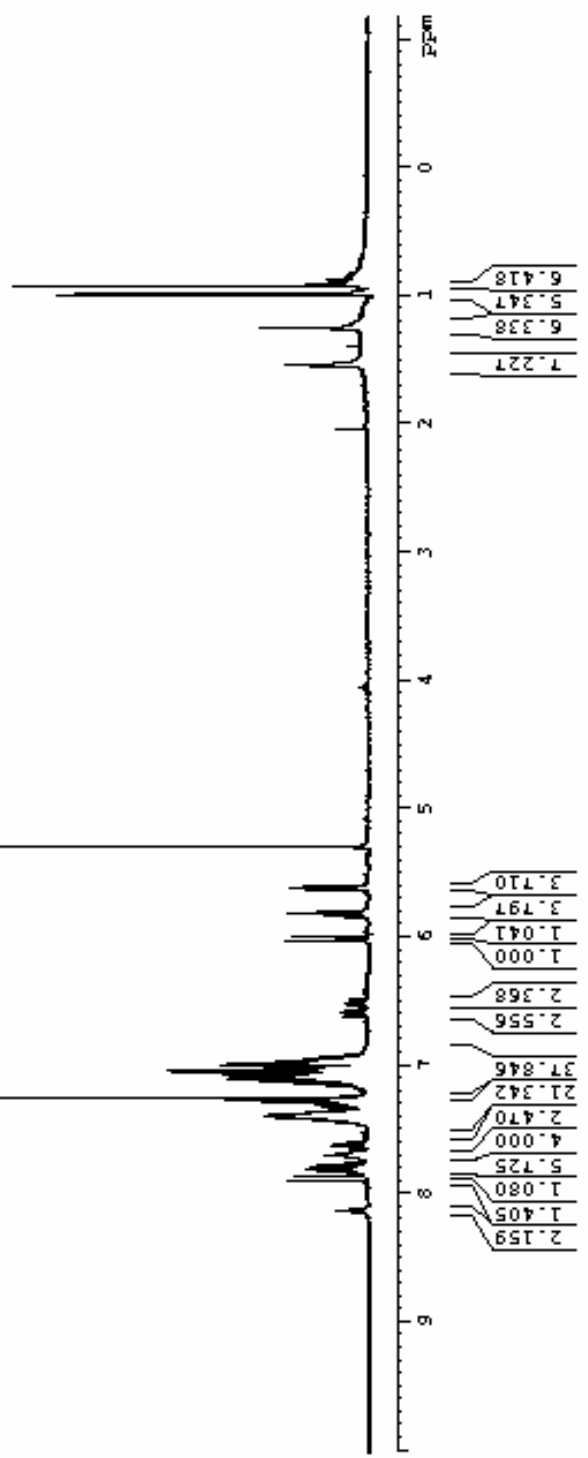




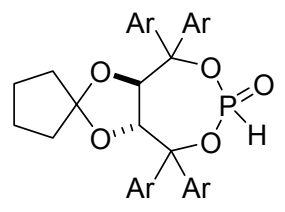

$\mathrm{Ar}=2-\mathrm{FPh}$

4k
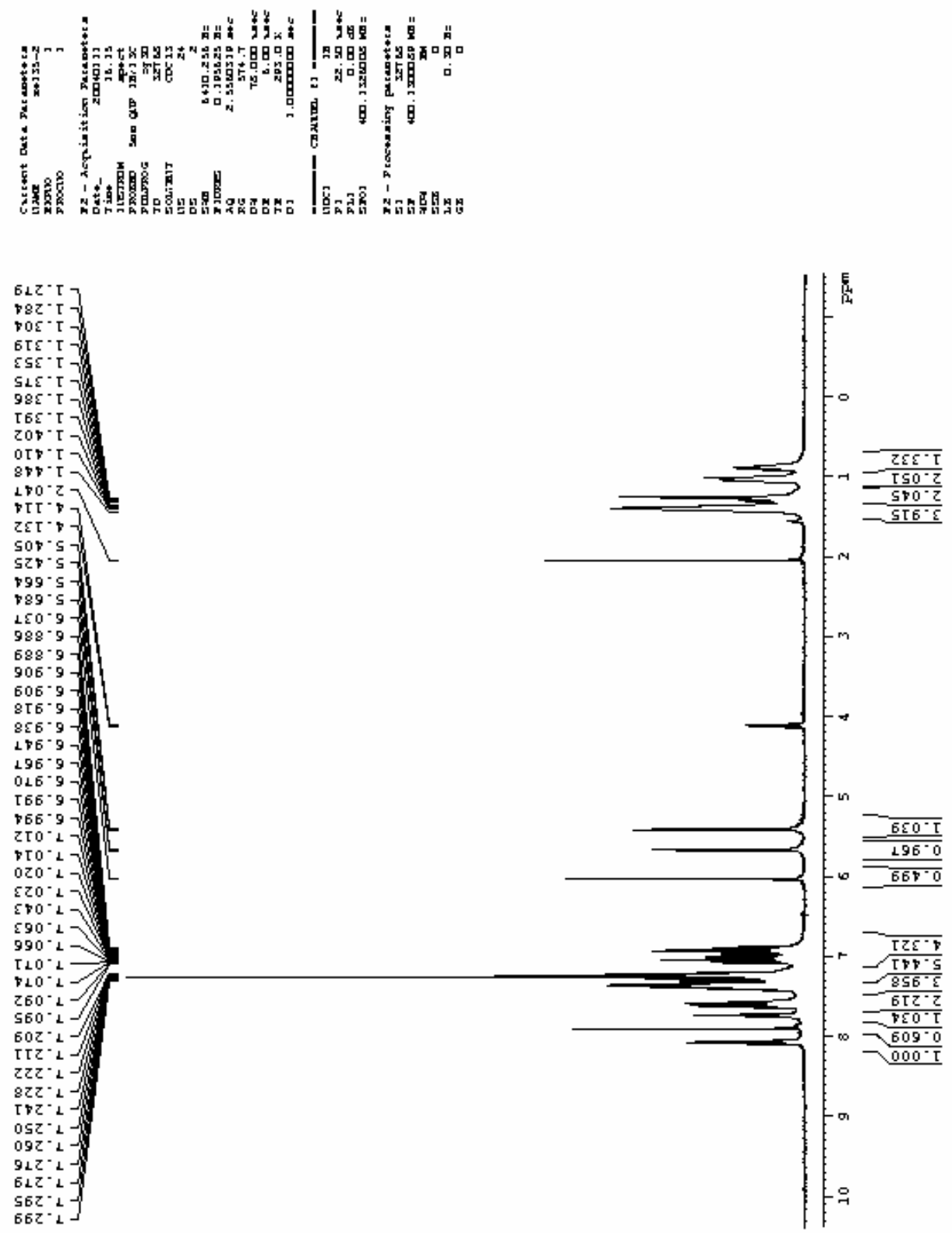


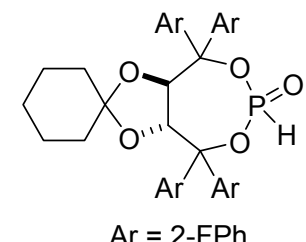

4I
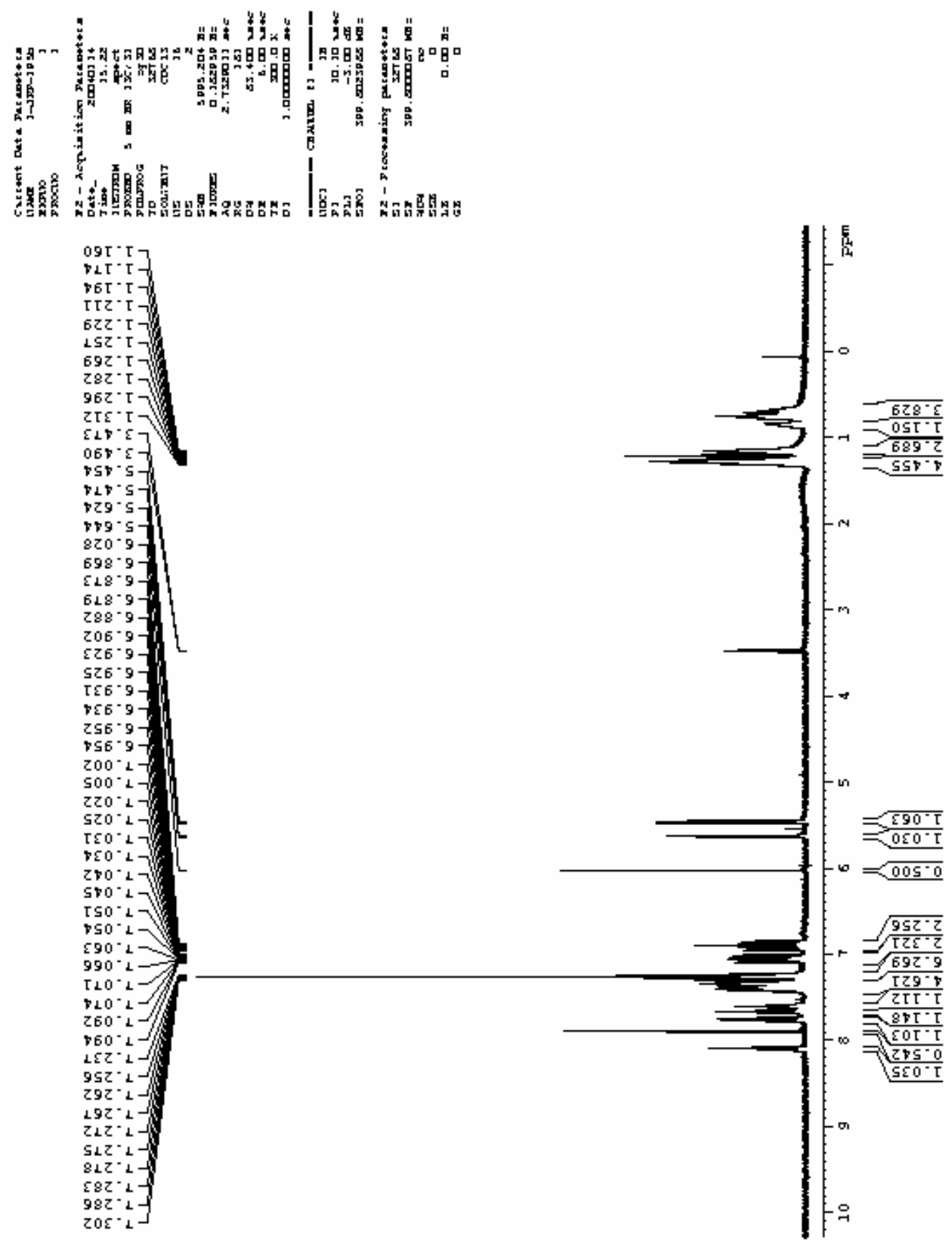


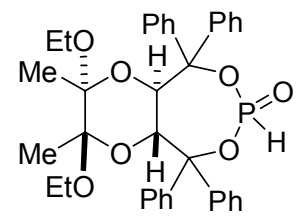

$4 m$
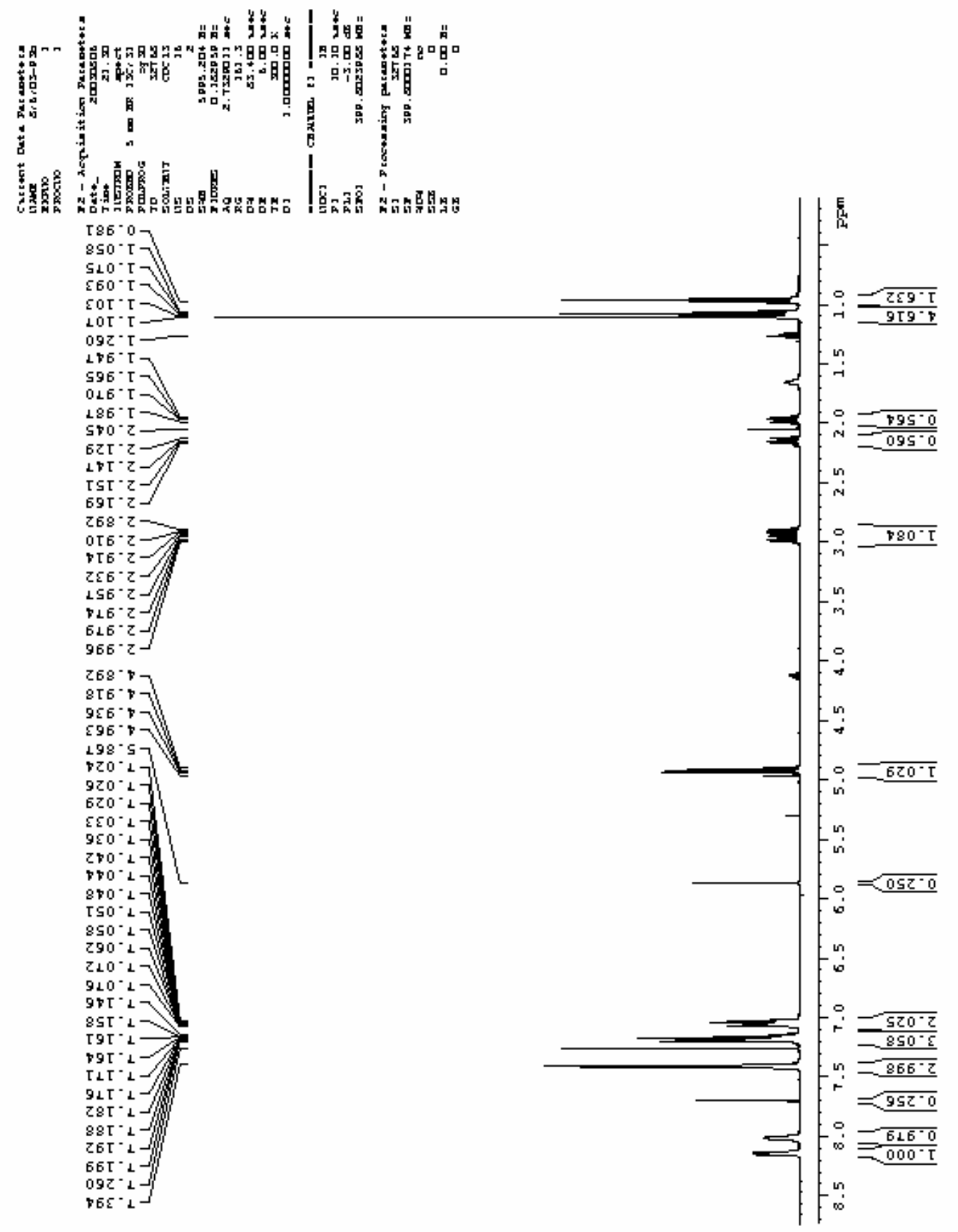


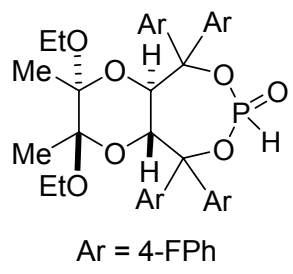

$4 n$

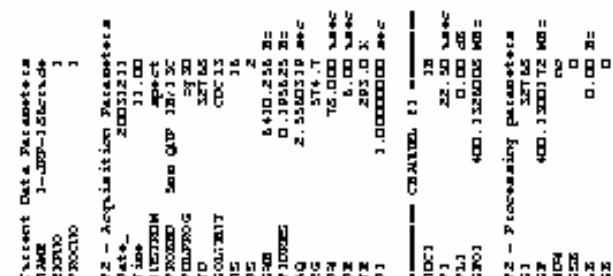

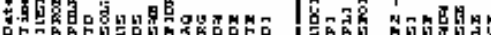
$25 \tau^{-} \mathrm{T}$
$\mathrm{grz}-\mathrm{T}$

$\operatorname{taz}-1-$

$5 \mathrm{sz} \cdot \mathrm{T}$

tos.T

$0,0 \cdot z-1$

的地 $z$

$1 z z \cdot z$

$152^{-2} \mathrm{z} 7$

200.8

$200-2$

820.5

$820.5-1$

150.-2

Tho.:-

$250 \cdot 2-\mathrm{X}$

$890^{\circ}-2-Y$

TSL 27

9L8.

$000 \cdot 9-$

$950.9-$

$\varepsilon 9.9$

$5 E \overline{5} \cdot 2$

$100^{\circ} 1$

$510-2$

$560^{\circ} \perp$

(2)

szt-1

$92 \mathrm{~T}^{\circ}-1$

$\operatorname{roc} \perp \mathrm{C}$

ozz: $\perp$

Eez: $\perp-$

epz-1-

5 to 1

$17 z-1$

onz: $1-$

ost 1

TSZ $\perp$

$\csc \alpha$

$\mathrm{s} G \mathrm{~L}-1$

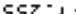

5s:- $2-$

$15 \mathrm{C}^{\circ} \perp$

25z. $1-$

$092 \div-1$

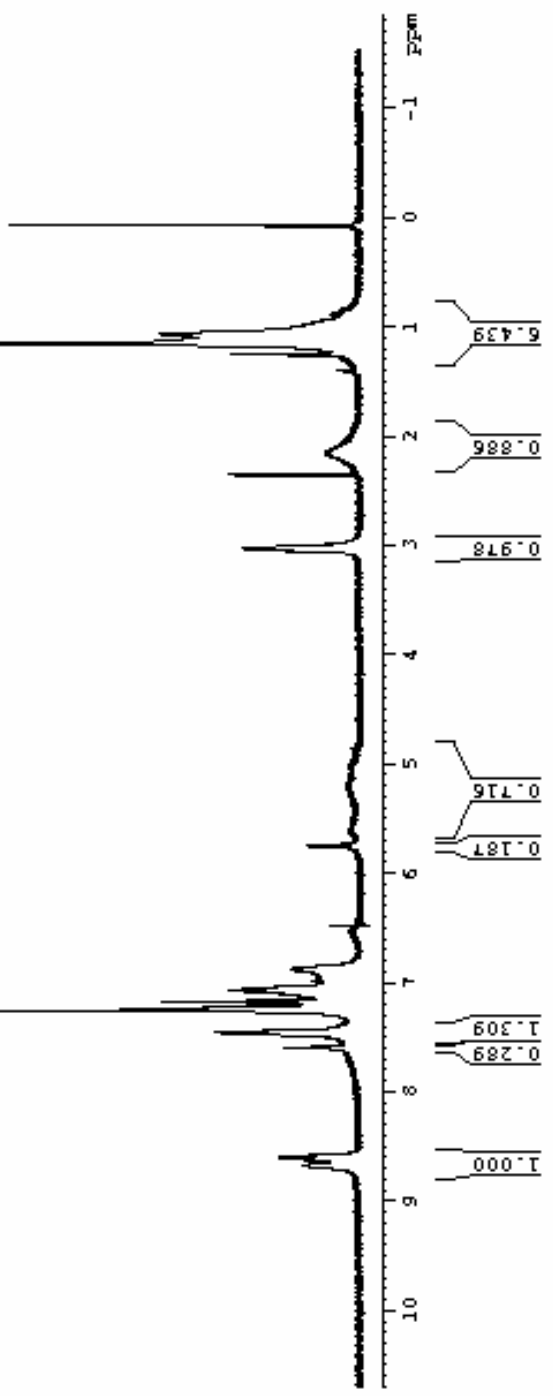



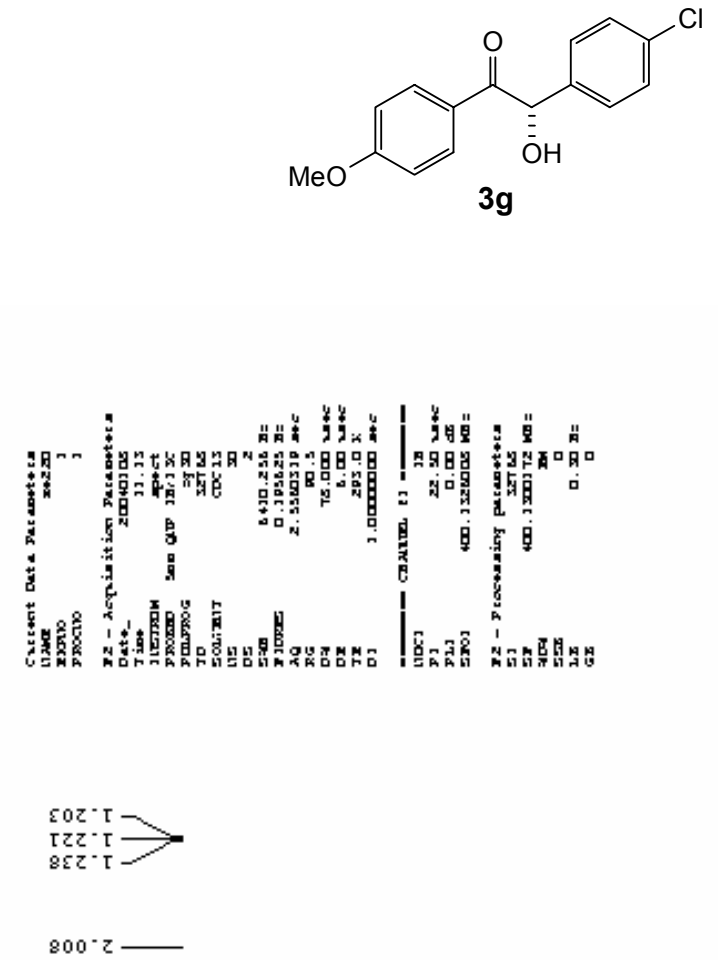

$200^{\circ} z$
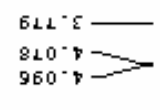

$960^{\circ} 5$

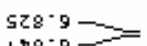

Lot. $=$

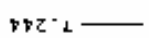

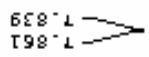
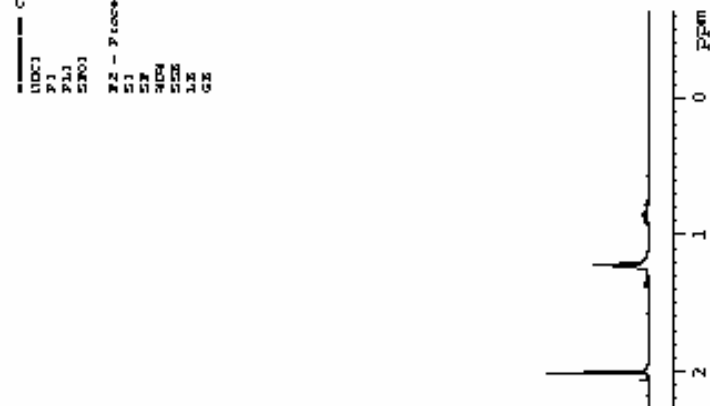


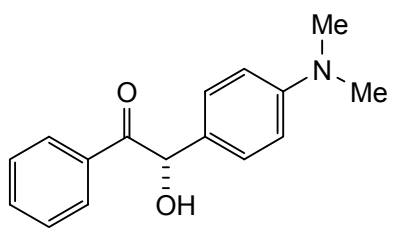

3h
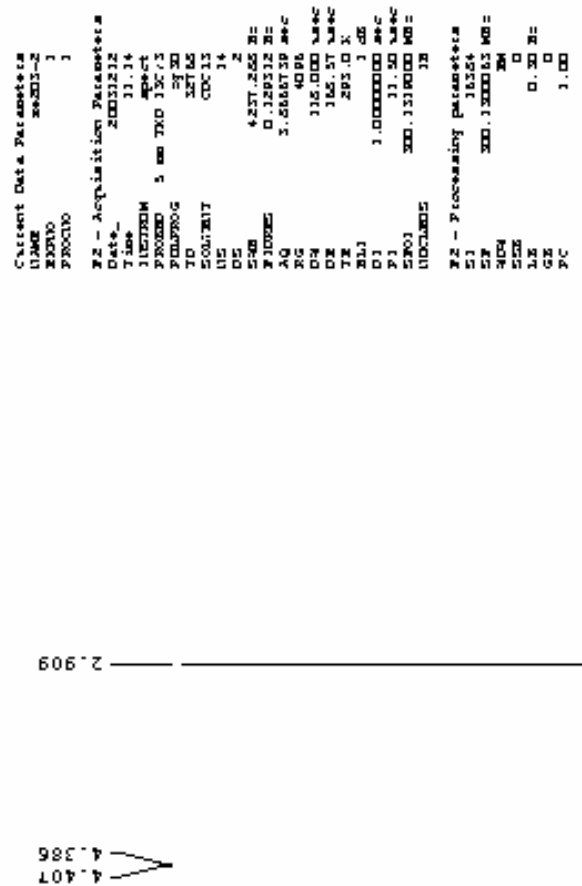

$990^{-5}-$

LEg- $9-1$

$252_{-2}^{2}$

टรT $1-7$

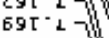

$59 \mathrm{~T}^{-} \mathrm{L}-\mathrm{W}$

बET $L-$

$592-1-\lambda$

O9S

507- 1

다 $\perp-$

LL" L

DET-L $L$

LET-L-

$800^{\circ} \perp-1$

CIE-L

OEE $\perp-$

SEE $L-$

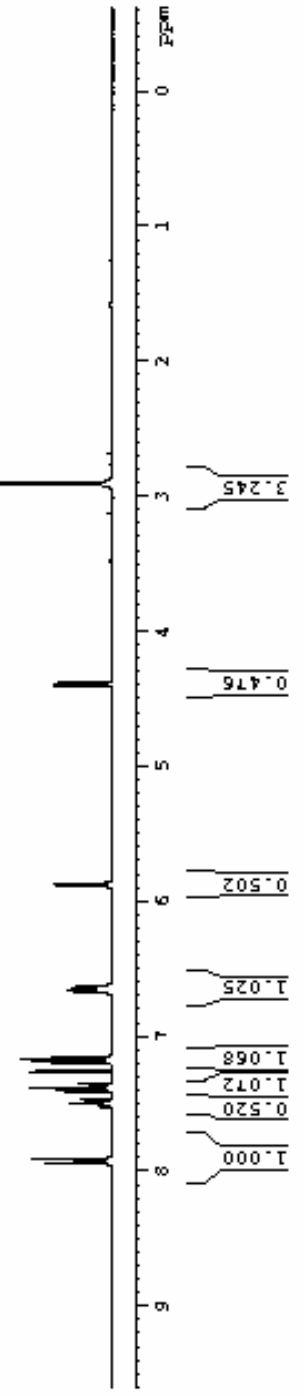



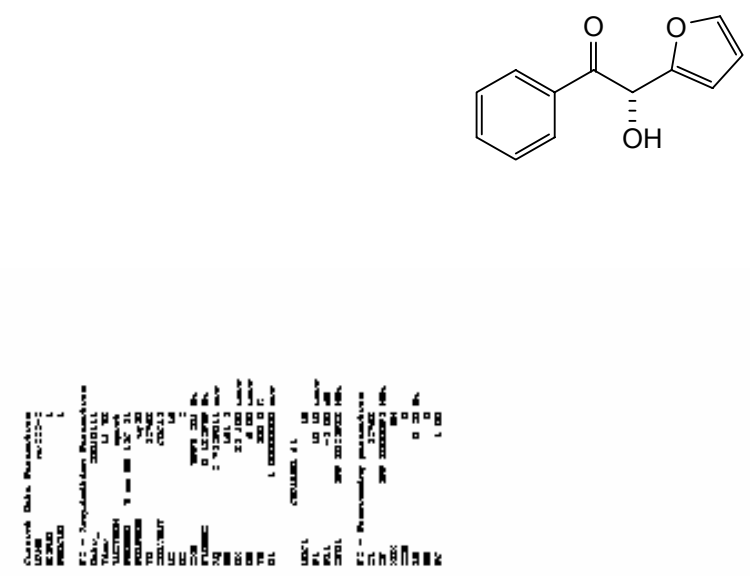

$9 g^{-}[$

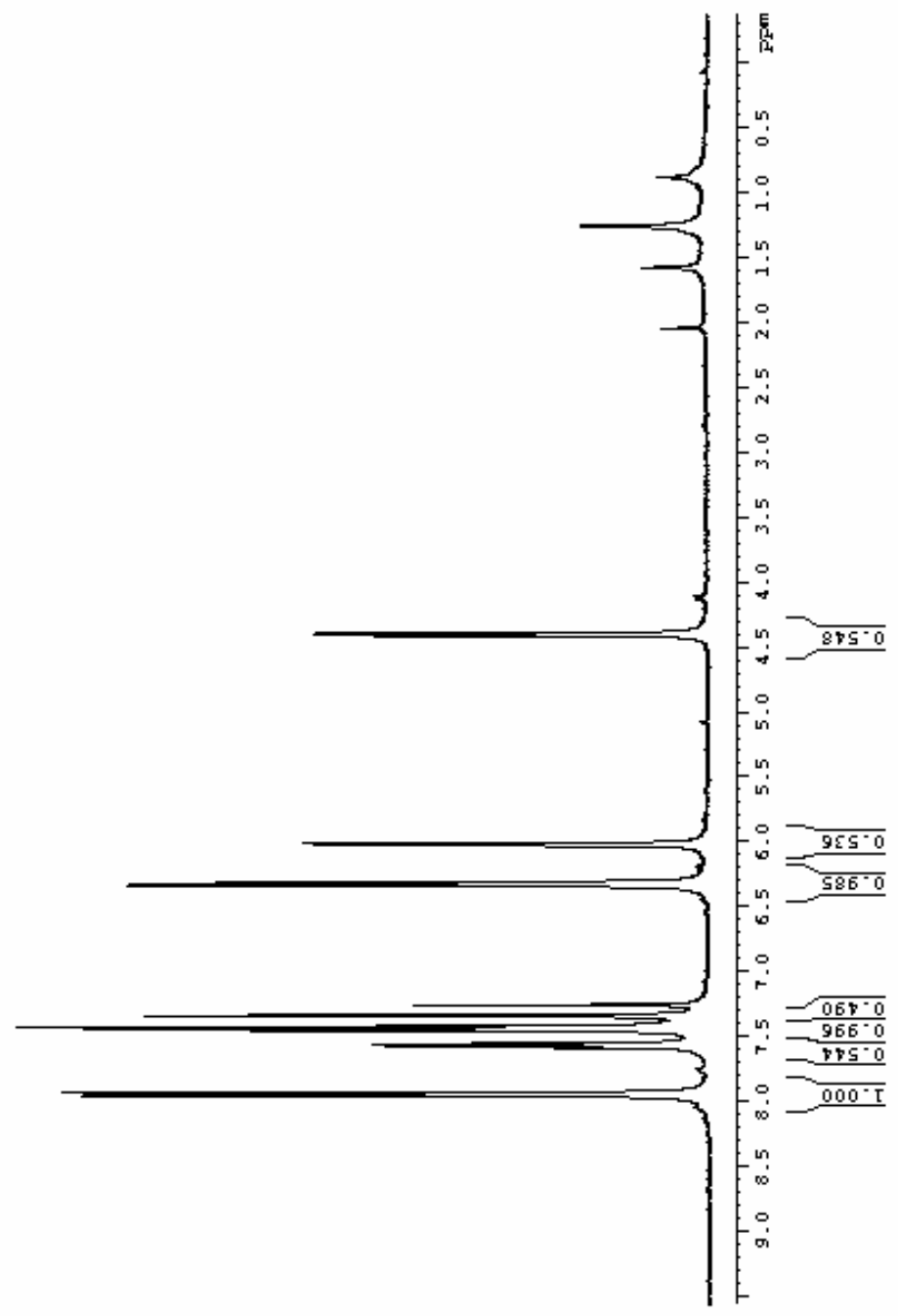

